\title{
An update on radiotracer development for molecular imaging of bacterial infections
}

\author{
Mick M. Welling ${ }^{1} \cdot$ Albertus W. Hensbergen $^{1} \cdot$ Anton Bunschoten $^{2} \cdot$ Aldrik H. Velders $^{2} \cdot$ Meta Roestenberg $^{3}$. \\ Fijs W. B. van Leeuwen ${ }^{1,2}$
}

Received: 24 December 2018 / Accepted: 1 February 2019 / Published online: 21 February 2019

(c) The Author(s) 2019

\begin{abstract}
Background Bacterial infections are still a major global healthcare problem. To combat the increasing antimicrobial resistance, early diagnosis of bacterial infections-including the identification of bacterial species-is needed to improve antibiotic stewardship and to help reduce the use of broad-spectrum antibiotics. To aid successful targeted antibiotic treatment, specific detection and localisation of infectious organisms is warranted. Nuclear medicine imaging approaches have been successfully used to diagnose bacterial infections and to differentiate between pathogen induced infections and sterile inflammatory processes.

Aim In this comprehensive review we present an overview of recent developments in radiolabelled bacterial imaging tracers. Methods The PubMed/MEDLINE and Embase (OvidSP) literature databases were systematically searched for publications on SPECT and PET on specific imaging of bacterial using specific guidelines with MeSH-terms, truncations, and completion using cross-references. Tracers in literature that was extensively reviewed before 2016 were not included in this update. Where possible, the chemical structure of the radiolabelled compounds and clinical images were shown.

Results In 219 original articles pre-clinical and clinical imaging of bacterial infection with new tracers were included. In our view, the highest translational potential lies with tracers that are specific to target the pathogens: e.g., ${ }^{99 \mathrm{~m}} \mathrm{Tc}-$ and ${ }^{68} \mathrm{Ga}$ labelled $\mathrm{UBI}_{29-41},{ }^{99 \mathrm{~m}} \mathrm{Tc}$-vancomycin, $m$ - $\left[{ }^{18} \mathrm{~F}\right]$-fluoro-PABA, [methyl- $\left.{ }^{11} \mathrm{C}\right]-D$-methionine, $\left[{ }^{18} \mathrm{~F}\right]-\mathrm{FDS},\left[{ }^{18} \mathrm{~F}\right]$-maltohexaose and $\left[{ }^{18} \mathrm{~F}\right]$-maltotriose. An encouraging note is that some of these tracers have already been successfully evaluated in clinical settings.

Conclusion This review summarises updates in tracer development for specific (pre-clinical and clinical) imaging of bacterial infections. We propsed some promising tracers that are likely to become innovative standards in the clinical setting in the near feature.
\end{abstract}

Keywords Infectious diseases $\cdot$ Radiotracers $\cdot$ Molecular imaging $\cdot$ Nuclear medicine $\cdot$ Pathogens

\section{Introduction}

Mick M. Welling

m.m.welling@lumc.nl

1 Interventional Molecular Imaging Laboratory, Department of Radiology, Leiden University Medical Center, Leiden, The Netherlands

2 Laboratory of BioNanoTechnology, Department of Agrotechnology and Food Sciences, Wageningen University \& Research, Wageningen, The Netherlands

3 Department of Parasitology and Department of Infectious Diseases, Leiden University Medical Center, Leiden, The Netherlands
Despite the success of treating bacterial infections with antibiotics, e.g., penicillins, quinolones, and glycopeptides, bacterial infections still pose a serious global health threat. Of 2 million bacterial infections each year in the USA alone at least 23,000 results in death, making an estimated economic impact of $\$ 55-70$ billion per year [1]. Antibiotics are key to the success of treating bacterial infections, but to retain antibiotics effectiveness, the use of broad-spectrum antibiotics should be restricted, and the use of dedicated small-spectrum antibiotics promoted. Antibiotic stewardship can, however, be applied much more efficiently when fast and accurate diagnosis are made. For example, the ability 
to accurately differentiate between aseptic loosening of artificial joints and pathogen infection could help to drastically reduce the use of broad-spectrum antibiotics in the future [2]. Characterization of the causative pathogen would be a second step needed to refine diagnosis. As the usability of the clinically available radiotracers is impaired by imaging of host inflammatory processes, further development of radiotracers that can image bacterial infections and discriminate them from sterile inflammatory processes and/or malignancies would benefit patients [3, 4].

Currently, microbiologic cultures or biomolecular techniques such as quantitative or broad range polymerase chain reaction (PCR) act as gold standard tools to diagnose causative pathogens [5]. These techniques are limited by the availability of tissue samples [6] and may not be suitable to detect dormant organisms or those that are hard to culture [7]. Radiological imaging techniques (CT, MRI, X-ray, and ultrasound) may aid in localising the infections [8], but these modalities are only able to visualise advanced diseases that have altered the patients natural tissue anatomy $[9,10]$. Molecular imaging solutions-as in oncology—have been shown to aid non-invasive diagnosis of bacterial infections in an early (non-disruptive) state [11]. Examples of these techniques are summarised in Table 1 and includes radiotracers such as ${ }^{67} \mathrm{Ga}$-citrate, ${ }^{99 \mathrm{~m}} \mathrm{Tc}$-labelled autologous leukocytes and $\left[{ }^{18} \mathrm{~F}\right]$-FDG, which are commonly used in western clinical practise $[9,12,13]$. For the current review, the PubMed/ MEDLINE and Embase (OvidSP) literature databases were systematically searched for publications on SPECT and PET on specific imaging of bacterial using specific guidelines with MeSH-terms, truncations, and completion using crossreferences. Tracers from literature that were reviewed before 2016 were not included in this update.

This review is an update of our earlier review published in 2013 [14], as well as other thematic reviews [12, 15-21].
Hereby we specifically focus on the status of radioactive tracer development of SPECT and PET infection imaging, their selectivity for infections with bacteria, and the potential for clinical translation.

\section{Antibacterial tracers}

In this chapter we describe infection-imaging tracers based on compounds that display antimicrobial activities. Often, such compounds show preferential binding of interaction with bacterial surfaces and structures.

\section{Imaging of infections with bacteria-specific antibodies}

As early as $1988,{ }^{99 \mathrm{~m}} \mathrm{Tc}-,{ }^{125} \mathrm{I}$ - and ${ }^{111} \mathrm{In}$-radiolabelled monoclonal antibodies (mAbs; molecular weight $\approx 150 \mathrm{kD}$ ) directed against bacterial epitopes, including the biofilmassociated pili, the 0 -side chain of Pseudomonas aeruginosa, and staphylococcal antigen $\mathrm{A}$, have been evaluated as SPECT imaging agents in bacterial infection models [22-25]. Although initial results were promising regarding to sensitivity (abscess-to-muscle ratios ranging between 5 and 12), the relatively large radiolabelled mAbs slowly cleared from the circulation resulting in high radiation burden and high background uptake in liver and other tissues. As a result, significant abscess-to-muscle ratios were only obtained 3 days post-injection. A mAb (1D9) directed against staphylococcal antigen A, Yersina adhesion A, or the Gram-positive bacterial surface molecule lipoteichoic acid was recently radiolabelled with either ${ }^{64} \mathrm{Cu}$ or ${ }^{89} \mathrm{Zr}$ $\left(t_{1 / 2}=12.7 \mathrm{~h}\right.$ and $78.4 \mathrm{~h}$ respectively $)$ and evaluated using PET imaging in mice [23, 24, 26]. 1D9 mAbs clearly

Table 1 Infection types, common causative bacterial pathogens (https://www.uptodate.com) and clinically approved radiotracer

\begin{tabular}{|c|c|c|}
\hline Infection & Common causative pathogens & Routinely used imaging tracer ${ }^{\mathrm{a}}$ \\
\hline Abdominal: e.g., appendicitis, pancreatitis & $\begin{array}{l}\text { Streptococci } \\
\text { S. aureus } \\
\text { Enterobacteriaceae }\end{array}$ & $\begin{array}{l}{ }^{99 \mathrm{~m}} \mathrm{Tc} \text {-leukocytes } \\
{\left[{ }^{18} \mathrm{~F}\right]-\mathrm{FDG}}\end{array}$ \\
\hline Pulmonary: e.g., pneumonia, tuberculosis, mediastinitis & $\begin{array}{l}\text { S. pneumoniae } \\
\text { S. aureus } \\
\text { M. tuberculosis }\end{array}$ & $\begin{array}{l}{\left[{ }^{18} \mathrm{~F}\right]-\mathrm{FDG}} \\
{ }^{67} \mathrm{Ga} \text {-citrate }\end{array}$ \\
\hline $\begin{array}{l}\text { Skeletal: e.g., osteomyelitis, spondylodiscitis, arthritis, infected } \\
\text { bone prostheses }\end{array}$ & S. aureus & $\begin{array}{l}{ }^{99 m} \mathrm{Tc}-\mathrm{MDP} / \mathrm{HDP} \\
{ }^{99 \mathrm{~m}} \mathrm{Tc}-\text { leukocytes } \\
{\left[{ }^{18} \mathrm{~F}\right]-\mathrm{FDG}}\end{array}$ \\
\hline Fever of unknown origin & Various [135] & ${ }^{67} \mathrm{Ga}$-citrate \\
\hline Infective endocarditis & $\begin{array}{l}\text { Streptococci } \\
\text { S. aureus } \\
\text { Enterococci }\end{array}$ & $\begin{array}{l}{ }^{99 \mathrm{~m}} \mathrm{Tc}-\text { leukocytes } \\
{ }^{99 \mathrm{~m}} \mathrm{Tc} \text {-Stannous colloids }\end{array}$ \\
\hline
\end{tabular}

${ }^{\text {a }}$ These tracers are mainly applied in western hospitals as nearly two-thirds of the world's population does not have adequate access to radiological services [130] 
targeted $S$. aureus at 3 days post-injection of the tracer with abscess-to-background ratios that were 2-3 times higher than in controls and comparable with ratios obtained with $\left[{ }^{18} \mathrm{~F}\right]$-FDG (Fig. 1A). However, 1D9 also yielded nonspecific uptake in infections with $E$. coli and in lipopolysaccharideinduced sterile inflamed tissues, which has been attributed to the $\mathrm{mAb}$ binding to $\mathrm{Fc}$ receptors omnipresent on the cell membrane of infiltrating macrophages [27, 28] (Fig. 1B).

\section{Bacterial infection imaging agents based on antibiotics}

Antibiotics are designed to penetrate diseased tissue and are rapidly cleared from non-target tissues in contrast to large antibodies. When combined with short half-life isotopes (e.g., ${ }^{99 \mathrm{~m}} \mathrm{Tc}$ and ${ }^{18} \mathrm{~F}$ ) such small molecules could substantially increase diagnostic speed and accuracy [29].

The fluoroquinolones are natural antibiotics and act as inhibitors of bacterial DNA synthesis. By binding to the enzyme-DNA complex, they block the DNA replication. The most studied natural antibiotic-based tracer is ${ }^{99 \mathrm{~m}} \mathrm{Tc}$ ciprofloxacin (Scheme 1), which was introduced in a clinical setting in 1997 [30]. An extensive evaluation of ${ }^{99 \mathrm{~m}} \mathrm{Tc}$ ciprofloxacin was performed under the supervision of the International Atomic Energy Agency (IAEA) including more than 900 patients with a suspected bacterial infection $[31,32]$. This study resulted in an overall sensitivity of $85 \%$ and a specificity of $82 \%$ which can be considered low for a bacteria-specific tracer. For example, combined radiolabelled ${ }^{111}$ In-leukocytes and ${ }^{99 \mathrm{~m}} \mathrm{Tc}$-MDP-SPECT of osteomyelitis, both non-specific tracers, already presented a sensitivity of $95 \%$ and a specificity of $93 \%$ [33]. Possible explanations for these unsatisfactory results, which limits its widespread clinical applicability, include radiochemical impurities, nonspecific binding and high efflux from the site of infection [34-37].

Shah et al. studied three additional radiolabelled antibiotics (Scheme 1) derived from last resort fluoroquinolones [38]: ${ }^{99 m}$ Tc-labelled garenoxacin dithiocarbamate [39], ${ }^{99 \mathrm{~m}}$ Tc-clinafloxacin dithiocarbamate [40], and ${ }^{99 \mathrm{~m}} \mathrm{TcN}-$ gatifloxacin dithiocarbamate [41]. In biodistribution studies in rats all these radiolabelled antibiotics demonstrated good uptake in multi-resistant $S$. aureus and penicillin-resistant streptococcal infections (abscess-to-muscle ratios between 4.4 and 6.5). Unfortunately, these findings were not supported by imaging data.

${ }^{99 \mathrm{~m}}$ Tc-labelled vancomycin and ${ }^{99 \mathrm{~m}} \mathrm{Tc}-\mathrm{HYNIC}$-vancomycin (Scheme 2; coordination chemistry unknown) were also studied for their potential to image bacterial infections [42, 43]. Vancomycin, to date the first line antibiotic treatment for methicillin-resistant $S$. aureus (MRSA), is a natural antibiotic that inhibits the bacterial cell wall synthesis of Gram-positive bacteria by binding to a peptidoglycan precursor and subsequent accumulation on the bacterial cell wall [44]. ${ }^{99 \mathrm{~m}} \mathrm{Tc}$-vancomycin showed preferential binding to bacteria in vitro, and in vivo biodistribution and targeting studies in $S$. aureus-infected rats and mice revealed rapid clearance via liver, intestines, and kidneys with high tracer uptake (abscess-to-muscle ratio of about 5) in infected muscles. These results were later successfully repeated with fluorescently labelled vancomycin in mice and in an ex-vivo human tissue model of infection [45].

The synthetic antibiotic trimethoprim (TMP) inhibits bacterial dihydrofolate reductase, an enzyme in the DNA synthesis and folate pathway of most bacterial species including Gram-positive, Gram-negative, mycobacterial species such as $M$. tuberculosis, and some parasites such as $T$. gondii. As a PET tracer, $\left[{ }^{18} \mathrm{~F}\right]$-fluoropropyl-trimethoprim ([ $\left.{ }^{18} \mathrm{~F}\right]$-FPTMP) (Scheme 3 ) showed high uptake in bacteria in vitro, and
A

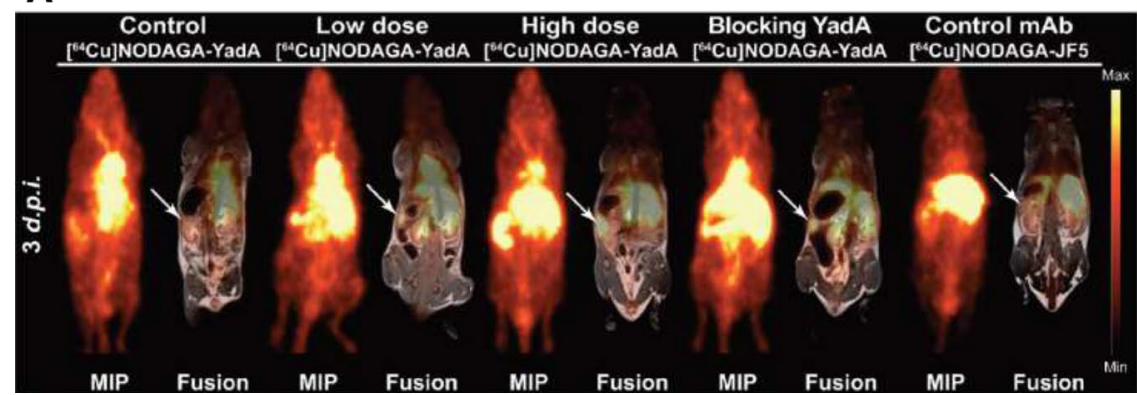

B

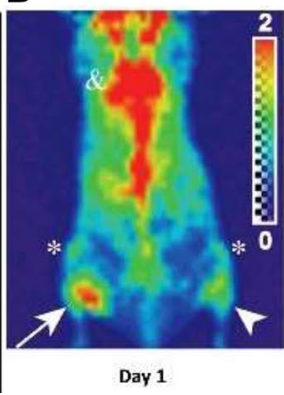

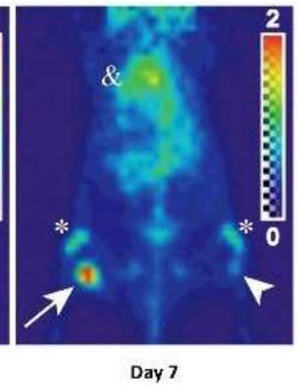

Fig. 1 a Administration of polyclonal non-radiolabelled YadA antibody $3 \mathrm{~h}$ prior to the injection of $\left[{ }^{64} \mathrm{Cu}\right]-N O D A G A-Y a d A$ (to block YadA) or the administration of the Aspergillus-specific tracer $\left[{ }^{64} \mathrm{Cu}\right]$-NODAGA-JF5 (control $\mathrm{mAb}$ ) into high-dose-infected mice served as the control treatments. Arrows indicate the positions of the spleens in the mice. From: Stefan Wiehr et al. Oncotarget.
2016;7(10):10,990-11,001. b In vivo IsaA-specific PET imaging of $S$. aureus infection with ${ }^{89} \mathrm{Zr}$-1D9. PET images of representative mice $[$ arrows $=w t$ infection; arrowheads $=\Delta$ isaA infection; $*$ $=$ knee joint; $\&=$ heart] From: Romero Pastrana et al. Virulence 2018:(9(1):262-272 
Scheme 1 Chemical structures of radiolabelled natural fluoroquinolone-based antibiotics ${ }^{99 \mathrm{~m}} \mathrm{Tc}$-ciprofloxacin, ${ }^{99 \mathrm{~m}} \mathrm{Tc}$-garenoxacin, ${ }^{99 \mathrm{~m}} \mathrm{Tc}$-clinafloxacin dithiocarbamate and ${ }^{99 \mathrm{~m}} \mathrm{TcN}$-gatifloxacin dithiocarbamate. The cationic complex of ${ }^{99 \mathrm{~m}} \mathrm{Tc}$-ciprofloxacin is caused by the interaction of ${ }^{99 \mathrm{~m}} \mathrm{TcO}^{3+}$ with two carboxylate anions. $M={ }^{99 \mathrm{~m}} \mathrm{Tc}$

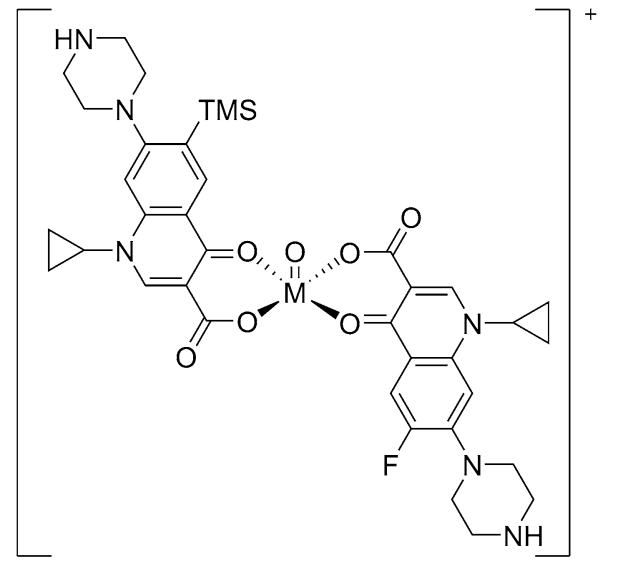

$\left[{ }^{99 \mathrm{~m}} \mathrm{Tc}\right]$ ciprofloxacin<smiles>C=C1C(C(C)=O)=CN(C2CC2)C2=C(Cl)c3c(F)cc(n3CC[C@H]3CC(S[Y4](C)(O)C(=O)[O-])=N3)C2=C1[O-]</smiles>

$\left[{ }^{99 \mathrm{~m}} \mathrm{Tc}\right] \mathrm{clinafloxacin}$ dithiocarbamate
$M={ }^{99 m} T c$

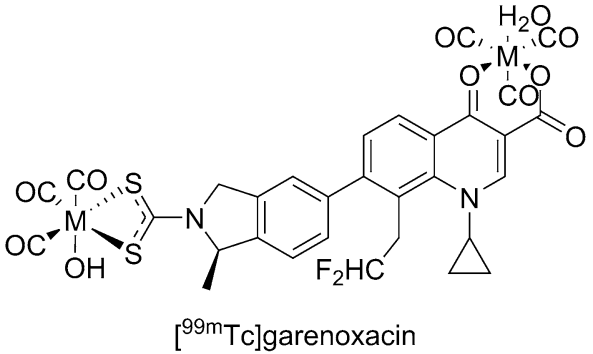

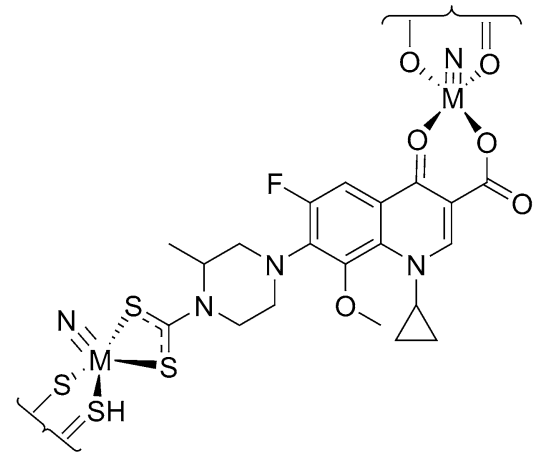

$\left.{ }^{99 \mathrm{~m}} \mathrm{Tc}\right] \mathrm{gatifloxacin}$ dithiocarbamate
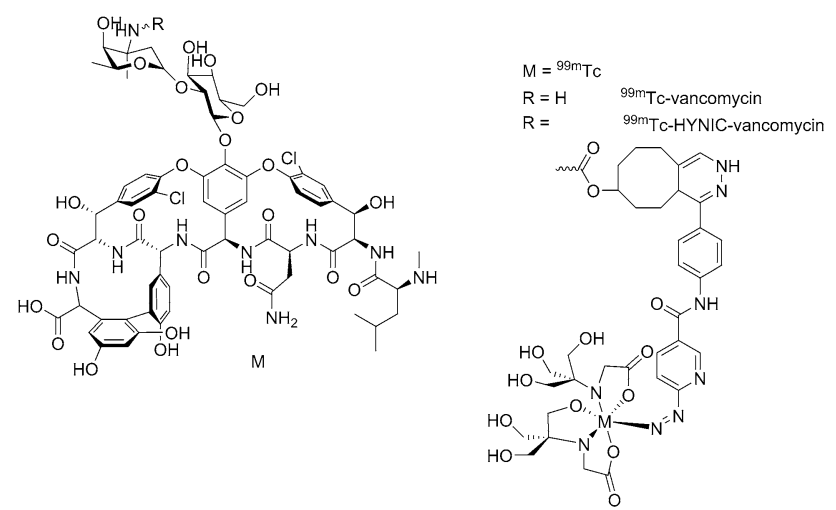

Scheme 2 Chemical structure of ${ }^{99 \mathrm{~m}} \mathrm{Tc}$-vancomycin (coordination unknown) and ${ }^{99 \mathrm{~m}} \mathrm{Tc}-\mathrm{HYNIC}$-vancomycin synthesised with inverse electron demand Diels-Alder click chemistry

abscess-to-muscle ratios between 2 and 3 in mice. However, because of the high background activity in liver, gall bladder and intestines, imaging of abdominal infections is limited [46]. Sites inoculated with less than $1 \times 10^{8}$ viable bacteria remained undetectable, which indicates a low sensitivity and could impair clinical imaging of low grade infections and monitoring the effect of antimicrobial therapy.<smiles>COc1cc(Cc2cnc(N)nc2N)cc(OC)c1OCCC[18F]</smiles>

Scheme 3 Chemical structure of the ${ }^{18} \mathrm{~F}$-labelled synthetic antibiotic $\left[{ }^{18} \mathrm{~F}\right]$-fluoropropyl-trimethoprim $\left(\left[{ }^{18} \mathrm{~F}\right]\right.$-FPTMP)

Radiolabelled isoniazid is based on the antibiotic known as isonicotinylhydrazide that has been used for the treatment of tuberculosis. Isoniazid is catalytically coupled to NADH in bacteria by a peroxidase enzyme and subsequently inhibits mycobacterial cell wall synthesis. ${ }^{99 \mathrm{~m}} \mathrm{Tc}$-isoniazid, was evaluated for imaging of M. tuberculosis in rabbits. ${ }^{99 \mathrm{~m}} \mathrm{Tc}$-labelled isonicotinic acid hydrazide was taken up in $M$. tuberculosis bearing lesions in the leg (abscess-to-muscle ratios of about 2.5). Additionally, in 6 patients with known tuberculosis infections in the lungs ${ }^{99 \mathrm{~m}} \mathrm{Tc}$-isoniazid demonstrated moderate the tracer uptake [47, 48] (Fig. 2). 

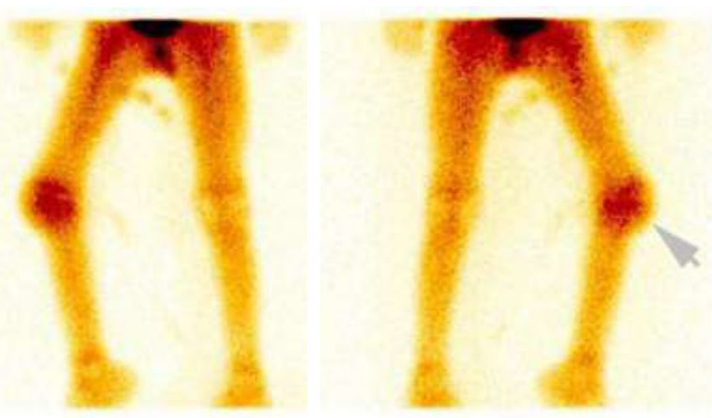

Ant 1h

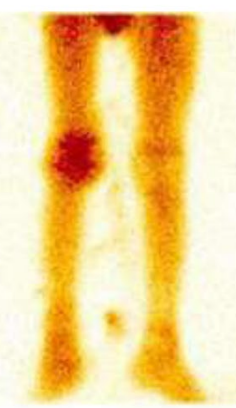

Ant $4 \mathrm{~h}$

Post 4h

Fig. 2 a Whole body gamma imaging using ${ }^{99 \mathrm{~m}}$ Tc-DTPA-bis(INH) in a patient having Mycobacterium tuberculosis infection. b Scan showing focus of the radiotracer concentration in the right knee joint (anterior and posterior images acquired at $1 \mathrm{~h}$ and $4 \mathrm{~h}$ ) From: Hazari et al. Open Nucl Med J 2014;6:33-42

\section{Imaging of infections with antimicrobial peptides}

Antimicrobial peptides (AMPs) were designed to rapidly kill a broad spectrum of pathogens, including Gram-positive and Gram-negative bacteria, fungi, parasites, and even enveloped viruses [49]. In low quantities, however, radiolabelled cationic AMPs have been successfully used for bacterial imaging. Cationic AMPs bind to negatively charged lipoteichoic acid, phospholipids, and lipopolysaccharides on bacterial membranes [50, 51]. The most widely investigated AMP for SPECT imaging of bacterial infections in mice, rats, and rabbits [52-54], ${ }^{99 \mathrm{~m}} \mathrm{Tc}-\mathrm{UBI}_{29-41}$, is a cationic synthetic fragment (TGRAKRRMQYNRR) derived of the natural cationic AMP ubiquicidin $\left(\mathrm{UBI}_{1-59}\right)$ [55]. From preclinical studies in vivo it has been shown that ${ }^{99 \mathrm{~m}} \mathrm{Tc}^{\mathrm{T}-\mathrm{UBI}_{29-41}}$ (coordination unknown) and ${ }^{99 \mathrm{~m}}$ Tc-HYNIC UBI ${ }_{29-41}$ (Scheme 4) accumulated specifically in infected tissues with abscessto-muscle ratios between 2 and $3[14,56,57]$. Both recently developed PET analogues ${ }^{68}$ Ga-NOTA-UBI ${ }_{29-41}[12,58-61]$ and ${ }^{68}$ Ga-NOTA-UBI ${ }_{31-38}$ [62] showed comparable uptake characteristics in infected thigh muscles in mice and rabbits. However, $\mathrm{UBI}_{29-41}$ also accumulated in infections with the yeast $C$. albicans [63], which reduces specificity of this tracer for imaging of bacterial infections alone.

It is encouraging to notice that ${ }^{99 \mathrm{~m}} \mathrm{Tc}$ - and ${ }^{68} \mathrm{Ga}-\mathrm{UBI}_{29-41}$ accumulated in bacterial infected tissues in patients (Figs. 3, 4). A pooled meta-analysis of clinical studies with ${ }^{99 \mathrm{~m}} \mathrm{Tc}$ $\mathrm{UBI}_{29-41}$ showed $95 \%$ sensitivity, $93 \%$ specificity and $94 \%$ accuracy in various clinical settings including prosthetic infections, diabetic foot infections, fever of unknown origin, osteomyelitis, mediastinitis, and appendicitis [55, 64, 65]. Due to its ability to discriminate between infection and sterile inflammation, general safety, the lack of side effects [66-69], and the successful transformation to kit formulations [59, 70-72], radiolabelled $\mathrm{UBI}_{29-41}$ has been proposed as a good candidate for applications in routine imaging [4, $9,61]$. Nevertheless, prospective multi- centre studies of both ${ }^{99 \mathrm{~m}} \mathrm{Tc}$ - and ${ }^{68} \mathrm{Ga}^{\mathrm{G}-\mathrm{UBI}_{29-41}}$ should still be carried out to achieve robust evidence of the accuracy in clinical imaging of bacterial infections. Additionally, the introduction of the
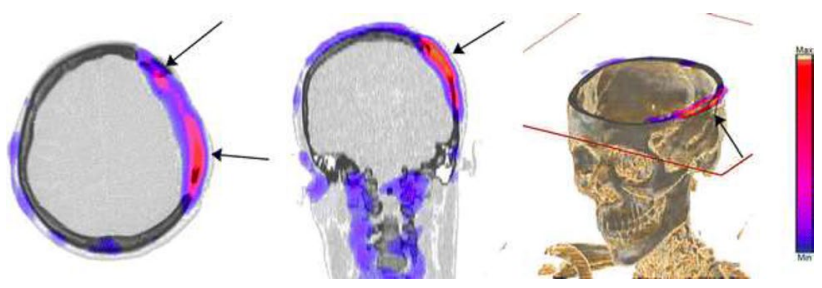

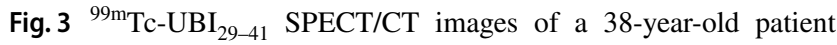
with a history of decompressive craniectomy. Axial, coronal and VRT images showing high uptake of the radiotracer on the scalp and bone borers (arrows). The culture was positive for $S$. epidermidis and Enterobacter cloacae From: Ferro-Flores G, et al. Clin Transl Imag. 2016;4(3):175-182

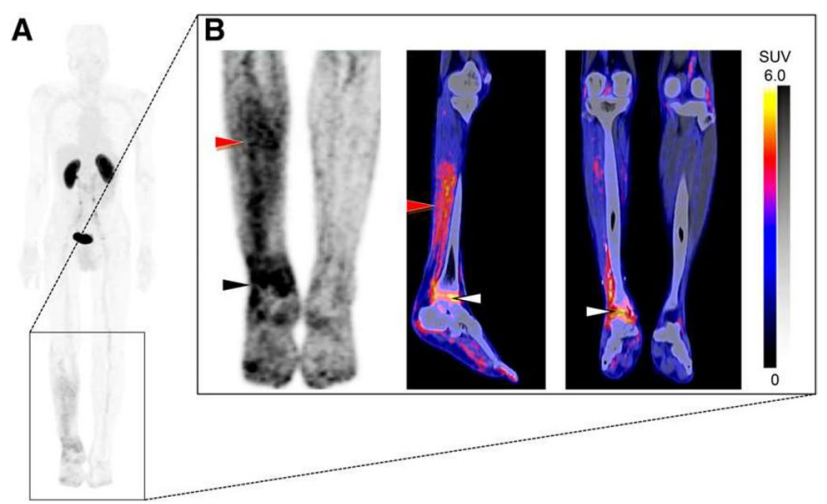

Fig. $4{ }^{68}$ Ga-NOTA-UBI PET/CT images (60 min p.i.) in representative patient with peripheral bone- and soft-tissue infection. a Wholebody maximum-intensity projection shows diffusely increased tracer uptake in right lower leg. b Detailed images demonstrate focal increased tracer uptake in ankle joint extending to adjacent bone (black and white arrows), as well as diffuse tracer uptake in calf muscles (red arrows); no significant uptake in contralateral leg was noted From: Ebenhan T, et al. J Nucl Med. 2018;59(2):334-339 


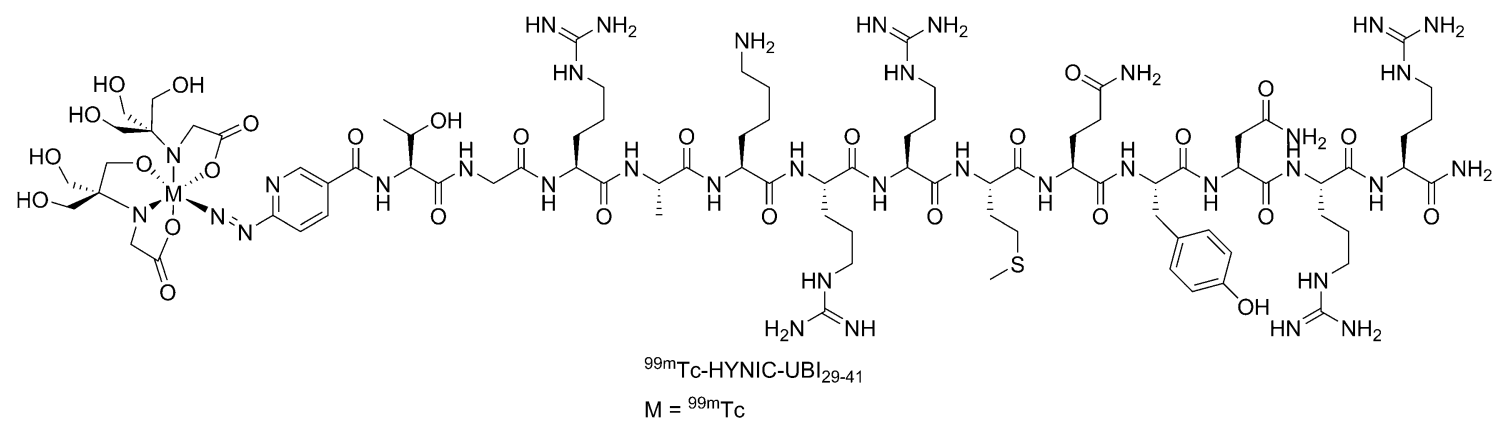

Scheme 4 Chemical structure of $\mathrm{UBI}_{29-41}$ directly labelled with ${ }^{99 \mathrm{~m}} \mathrm{Tc}$ (top panel) or conjugated to HYNIC to enable labelling with ${ }^{99 \mathrm{~m}} \mathrm{Tc}$ (bottom panel). $M={ }^{99 \mathrm{~m}} \mathrm{Tc}$. Of direct labelled $\mathrm{UBI}_{29-41}$ the coordination of ${ }^{99 \mathrm{~m}} \mathrm{Tc}$ in the peptide backbone is unknown

hybrid tracer ${ }^{111}$ In-DTPA-Cy5-UBI $29-41$ allowed radioactive and fluorescence imaging of bacterial infections using SPECT and optical imaging modalities [73]. The hybrid imaging approach for imaging of deep infections it is postulated, when combined with a radioisotope, sites of infection can be identified using non-invasive nuclear imaging techniques and guide the subsequent surgical intervention and fluorescence guided surgery [74, 75].

Research with other AMPs for pre-clinical imaging of infections is still ongoing [52, 76-79]. Recently, a synthetic analogue of the natural cyclic antimicrobial peptide depsidomycin ( ${ }^{68} \mathrm{Ga}$-DOTA-TBIA101, Scheme 5), was investigated for its characteristic to target bacteria. Depsidomycin itself is a natural AMP isolated from S. lavendofolae and exhibits antimicrobial activities against i.e., drug-resistant M. tuberculosis [80]. As a tracer, ${ }^{68}$ Ga-DOTA-TBIA101 detected muscular $E$. coli infections in mice with abscessto-muscle ratios between 1.2 and 1.6 [81], S. aureus (with a target-to-nontarget ratio between 1.2 and 1.3), and M. tuberculosis (abscess-to-muscle ratios between 2.0 and 2.8) infections in rabbits [82]. These results indicate a preference for infections with $M$. tuberculosis, but unfortunately the tracer also accumulated at sites of sterile inflammation which limits its translational potential.

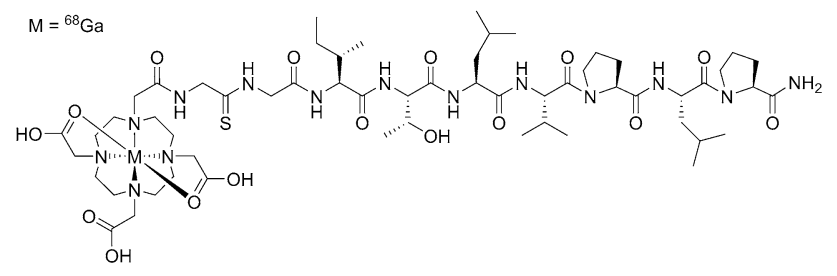

${ }^{68}$ GaDOTA-TBIA101

Scheme $5{ }^{68} \mathrm{Ga}$-labelled TBIA101 through conjugation with the DOTA chelate. $M={ }^{68} \mathrm{Ga}$

\section{Imaging of infections with radiolabelled bacteriophages}

Bacteriophages belong to a class of viruses that are able to bind to specific surface receptors on selective bacteria because they use bacteria as host for their replication [83]. Thus, bacteriophages as radiotracers have potential for imaging specific strains of bacteria. Already in the first decades of the last century bacteriophages were considered an asset in the treatment of bacterial infections [84]. The earliest study with radiolabelled bacteriophages as a tracer for bacteria was performed by Rusckowski et al.[85]. During their study, they conjugated the bacteriophage M13 with mercaptoacetyltriglycine $\left(\mathrm{MAG}_{3}\right)$ to enable facile labelling with ${ }^{99 \mathrm{~m}} \mathrm{Tc}\left({ }^{99 \mathrm{~m}} \mathrm{Tc}-\mathrm{MAG}_{3}-\mathrm{M} 13\right)$ for imaging infections with three different bacterial species, including two E. coli species and $S$. aureus in mice. Uptake in bacterially-infected tissues was higher (abscess-to-muscle ratio of 2.3) than in sterile inflammations or normal tissue. These results, as they were promising, were downplayed due to poor image quality as shown in Fig. 5 for $S$. aureus. Interestingly, the intensity of tracer uptake waned over time as a result the antimicrobial effect that the phages had on the bacteria. Furthermore, high uptake in thyroid glands, was observed indicating release of ${ }^{99 \mathrm{~m}} \mathrm{Tc}$ and clearance of the phage was indicated by uptake in the liver and kidneys [85, 86]. In a second attempt, four different bacteriophages (phages P22, E79, VD-13, and phage 60) were radiolabelled with ${ }^{99 \mathrm{~m}} \mathrm{Tc}$ using the chelator $\mathrm{MAG}_{3}$ [86]. Biodistribution studies were performed for different bacterial species (P. aeruginosa, E. coli, S. enterica, and $K$. pneumoniae). Of the studied agents, only bacteriophage ${ }^{99 \mathrm{~m}} \mathrm{Tc}_{\mathrm{MAG}}-\mathrm{MA}_{3}$-E showed specificity for P. aeruginosa. (abscess-to-muscle ratios between 10 and 28; a fourfold increase compared to other bacteria). The other radiolabelled phages accumulated in infected thigh muscles with abscess-to-muscle ratios between 2 and 5 suggesting nonspecific uptake. Uptake of radiolabelled phages in the liver 


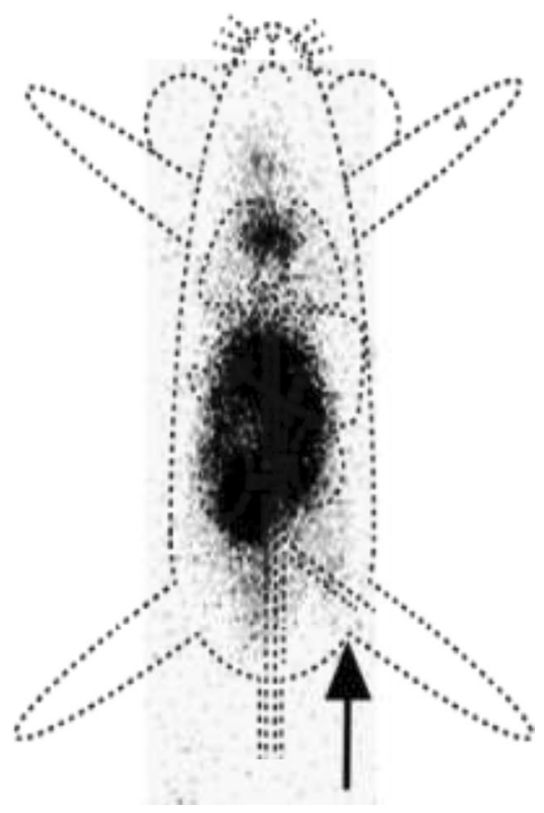

Fig. 5 Whole-body images at $3 \mathrm{~h}$ after administration of ${ }^{99 \mathrm{~m}} \mathrm{Tc}$ MAG3-M13 phage to mice with a $S$. aureus infected thigh (arrow) Mary Rusckowski et al. J Nucl Med 2004;45:1201-1208

(13.1\% ID/g) and intestines (11.1\%ID/g) was high (Fig. 5). More recently, Cardoso et al. [87] evaluated in a biodistribution study the ${ }^{99 \mathrm{~m}} \mathrm{Tc}$-labelled bacteriophage PP7 for detecting $P$. aeruginosa infections in mice and this tracer had an increased accumulation in $P$. aeruginosa-infected tissues (abscess-to-muscle ratio $4.2 \pm 0.3$ ) compared to sterile inflammations (abscess-to-muscle ratio $2.5 \pm 0.4$ ).

Radiolabelled bacteriophages, whereof some show specific binding to bacteria as was demonstrated in the imaging studies. Unbound phages rapidly accumulated in the liver and intestines. Due to the poor imaging quality the translational properties of radiolabelled phages for imaging of bacterial infections is limited.

\section{Infection imaging agents based on bacterial metabolic activities}

Efforts have been made to develop tracers based on molecules that participate in metabolic processes that are either unique to bacterial/prokaryotes or more dominantly present in bacteria. These include molecules that are used as an energy source, building block for cell wall synthesis or are metabolic substrates for DNA synthesis, proliferation and virulence. Certain metabolic enzymes are expressed only in bacteria or even in specific strains of bacteria and as such these processes are ideal targets for specific imaging of bacteria and this is a different approach than with tracers based on antimicrobial activities.

\section{Imaging of thymidine kinase activity}

The SPECT tracer $\left[{ }^{125} \mathrm{I}\right]$-FIAU or PET tracer $\left[{ }^{124} \mathrm{I}\right]$-FIAU (Scheme 6) is based on a nucleoside substrate for thymidine kinase. These tracers have been investigated for the imaging of infections in mice with E. coli, S. aureus and other bacterial strains $[88,89]$. Image quality depended on the type of pathogen and host metabolism activities. For example, mitochondrial thymidine kinase in cancerous malignancies reduced the specificity [90, 91]. Promising results were obtained with imaging $\left[{ }^{124} \mathrm{I}\right]$-FIAU in patients $(n=8)$ with proven musculoskeletal infection (Fig. 6) [89]. Unfortunately, a more recent multi-centre study reported low specificity and poor imaging quality in patients $(n=34)$ with suspected prosthetic joint infection [92], which limited further exploitation of [ $\left[{ }^{124}\right.$ I]-FIAU.

\section{Imaging the folic acid synthesis pathway}

A radiofluorinated analogue of $p$-aminobenzoic acid $\left(m-\left[{ }^{18} \mathrm{~F}\right]\right.$-fluoro-PABA) (Scheme 7$)$, which is a substrate for folic acid synthesis in prokaryotes [93], was evaluated in rats infected with methicillin-resistant or -sensitive $S$. aureus [94]. Bacteria use folic acid for their synthesis of nucleic acids. In this rat model, PET imaging with $m$ - $\left[{ }^{18} \mathrm{~F}\right]$ fluoro-PABA imaging revealed rapid uptake in bacterial infections (abscess-to muscle ratio $\approx 8$ ) (Fig. 7) and because the uptake in sterile inflammatory sites was about nine-fold lower, $m$ - $\left[{ }^{18} \mathrm{~F}\right]$-fluoro-PABA can be considered specific for the imaging of bacterial infections. Interestingly, $m$ - $\left[{ }^{18} \mathrm{~F}\right]$-fluoro-PABA showed reduced uptake in oxacillin treated $S$. aureus tissues, which indicates that this tracer can be applied in response monitoring applications.

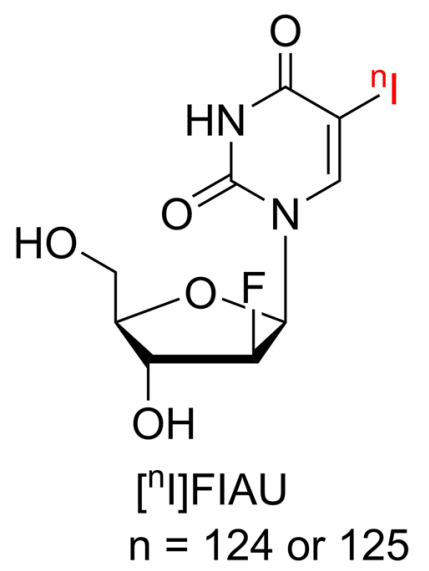

Scheme 6. Chemical structure of fialuridine ([$\left.\left.{ }^{\mathrm{I}} \mathrm{I}\right]-\mathrm{FIAU}\right)-$ based SPECT $(n=125)$ or PET $(n=124)$ tracers 

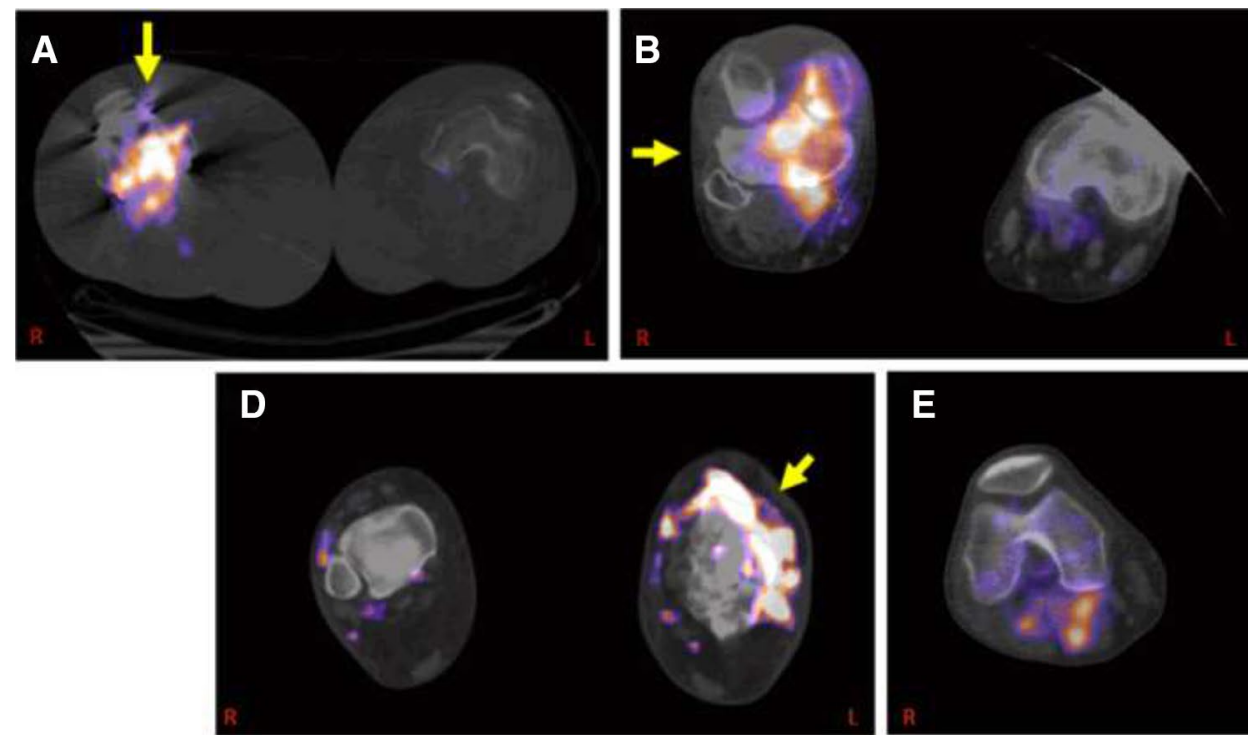

Fig. $6\left[{ }^{124}\right.$ I]-FIAU signal in established infections as imaged by PET/ CT: Fused PET and CT images, taken at $2 \mathrm{~h}$ after radiotracer administration, are shown for the following cases. a Septic arthritis (right knee, Patient 1), b septic arthritis (right knee, Patient 4), c osteomy-<smiles>Nc1ccc(CC(=O)O)c(Br)c1</smiles>

$m-\left[{ }^{18} \mathrm{~F}\right]$ fluoro-p-aminobenzoic acid

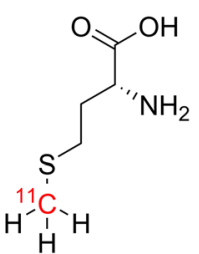

[methyl- $\left.{ }^{11} \mathrm{C}\right] \mathrm{D}$-methionine
Scheme 7 Chemical structures of the $\left[{ }^{18} \mathrm{~F}\right]$-labelled $p$-aminobenzoic acid derivative and the $\left[{ }^{11} \mathrm{C}\right]$-labelled $\mathrm{D}$-methionine derivative for the imaging of the folic acid synthesis pathway

As 2- $\left[{ }^{18} \mathrm{~F}\right]$-fluoro-PABA poorly interacts with mammalian cells, this tracer holds potential for clinical translation.

Another substrate related to the folate synthesis pathway, methionine, is a metabolite essential for methylation pathways. This compound, which has been studied in the context of imaging $S$. aureus and E. coli infections, is an essential amino acid and is readily incorporated into $E$. coli muropeptides and plays an important role in cell signalling. Based on the uptake of [methyl- ${ }^{11} \mathrm{C}$ ]-D-methionine muscle infections in mice with viable $E$. coli and $S$. aureus could be differentiated (with 6-9 times higher abscess-to-inflammation ratios) from sites injected with heat-killed bacteria (Scheme 7) [95]. However, before considering clinical imaging of infections, additional imaging experiments at later intervals are warranted to study the concomitant high tracer uptake in

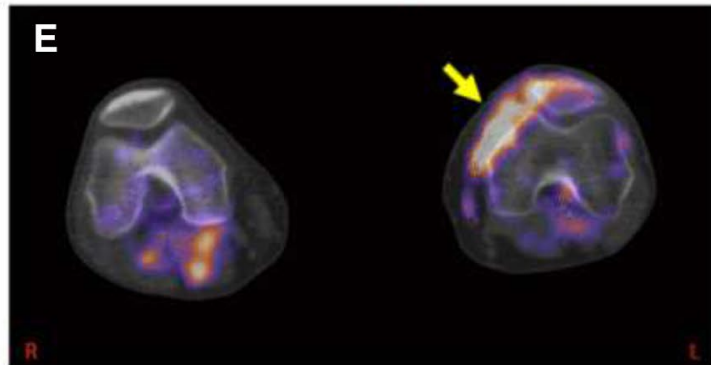

elitis (left distal tibia, Patient 5), d cellulitis (left lower extremity, Patient 6), e necrotizing septic arthritis (left knee, Patient 8) From: Diaz LA, et al. PLoS one. 2007;2(10):e1007

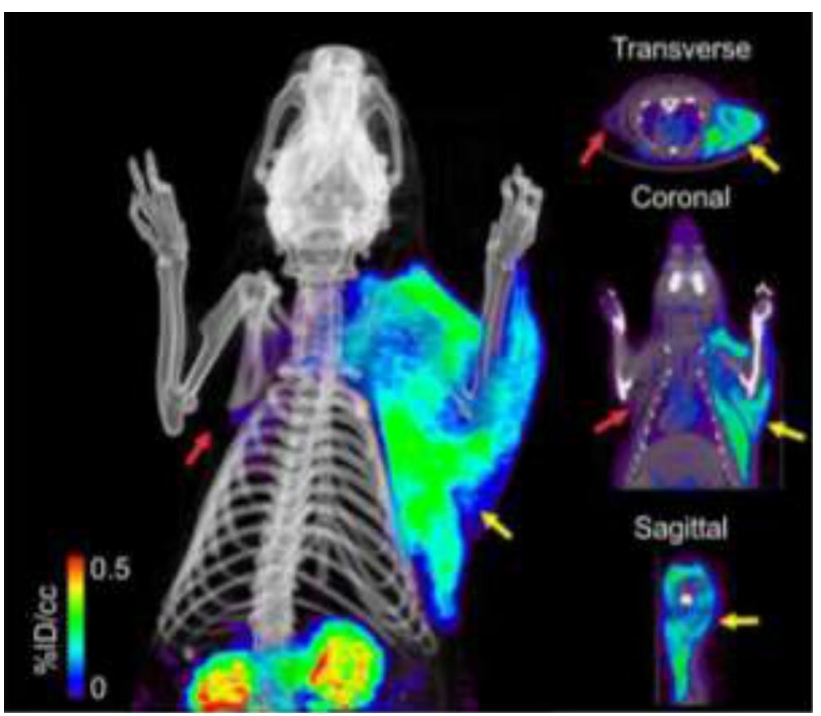

Fig. $72-\left[{ }^{18}\right.$ F]F-PABA PET/CT images of rats with $S$. aureus infection in the right triceps (yellow arrow) and sterile inflammation in the left triceps (red arrow). The images are a three-dimensional projection, transverse, coronal and sagittal views $60-80$ min post tracer injection From: Zhang Z, et al. ACS Infect Dis. 2018;4(11):16351644

non-infected tissues including liver (15\%/ID) and intestines (7\%/ID), the latter of which, according to the authors, may be related to the presence of non-pathogenic bacteria in the microbiome [96]. 


\section{Imaging of the iron metabolism}

Siderophores, metal-chelating peptides, [97] are another example of prokaryote-specific tracers. These low-molecular-mass iron transporters are used by most bacteria, fungi, and some plants to scavenge iron from their environment which is critical because of a wide variety of metabolic processes. The peptides have the ability to coordinate $\operatorname{In}^{3+}$ and $\mathrm{Ga}^{3+}$ ions, as ${ }^{111} \mathrm{In}$ - or ${ }^{67} \mathrm{Ga}$-labelled siderophores and these tracers are known to be taken up by bacteria and fungi [98-100]. When using ${ }^{68} \mathrm{Ga}$, the siderophores support PET imaging (Scheme 8). A proof-of-principle in vivo study was performed with the fungus $A$. fumigatus, the bacterium $S$. aureus and a sterile inflammation in a lung and thigh muscle infection model in rats with ${ }^{68} \mathrm{Ga}$-labelled triacetylfusarinine $\left({ }^{68} \mathrm{Ga}-\mathrm{TAFC}\right)$ [101]. The tracer uptake was prominent in infected sites with A. fumigatus (abscess-to-background ratios between 5.8 and 6.6), but also some uptake in sterile inflammation sites was visible (albeit lower than for $A$. fumigatus but clearly visible; no inflammation-to-background ratios were given). No uptake was noticed in tissues infected with S. aureus which limits the clinical use of radiolabelled siderophores for imaging of bacterial infections.

\section{Imaging carbohydrate metabolism}

In bacterial infection, the responding endogenous inflammatory cells increase glycolysis as a source of energy. This increase makes the clinically approved PET tracer 2-Deoxy-2$\left[{ }^{18} \mathrm{~F}\right]$-fluoro-D-glucose $\left(\left[{ }^{18} \mathrm{~F}\right]-\mathrm{FDG}\right)$ the most widely used radiotracer for non-invasive imaging of infections. Because uptake of glucose can also be related to other phenomena [4, 102, 103], there is a demand for alternatives with a higher specificity and sensitivity for bacterial infections. In 2008, Li et al. reported the reduction of $\left[{ }^{18} \mathrm{~F}\right]$-FDG using $\mathrm{NaBH}_{4}$ resulting in 2-deoxy-2-[ $\left.{ }^{18} \mathrm{~F}\right]$-fluoro-sorbitol $\left(\left[{ }^{18} \mathrm{~F}\right]\right.$-FDS) (Scheme 9), an analogue of sorbitol [104]. Because sorbitol is a substrate that is only metabolised by Enterobacteriaceae, a metabolic pathway that does not exist in mammalian cells [104, 105], it was reasoned that $\left[{ }^{18} \mathrm{~F}\right]$-FDS could also be a promising probe capable of distinguishing infections with $E$. coli [106] or $K$. pneumoniae [107] from infections with Gram-positive bacteria as well as from sterile inflammations. Indeed, E. coli infections could be properly visualised with $\left[{ }^{18} \mathrm{~F}\right]-\mathrm{FDS}$ in mice and the uptake in infected tissues increased about eight-fold compared to sterile inflammatory sites. Additionally, imaging of $E$. coli infections with $\left[{ }^{18} \mathrm{~F}\right]$-FDS was performed and, after antimicrobial treatment with ceftriaxone, infected tissues decreased eight-fold tracer uptake. This is a strong indication that $\left[{ }^{18} \mathrm{~F}\right]$-FDS can be employed for monitoring the effect of antimicrobial interventions [107, 108].
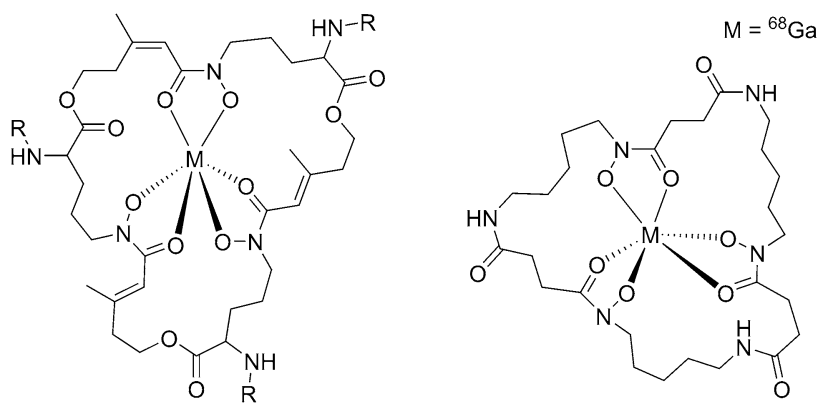

${ }^{68} \mathrm{Ga}-\mathrm{TAFC} \quad \mathrm{R}=\mathrm{C}(\mathrm{O}) \mathrm{CH}_{3}$

${ }^{68} \mathrm{Ga}-\mathrm{FUS} \quad \mathrm{R}=\mathrm{H}$
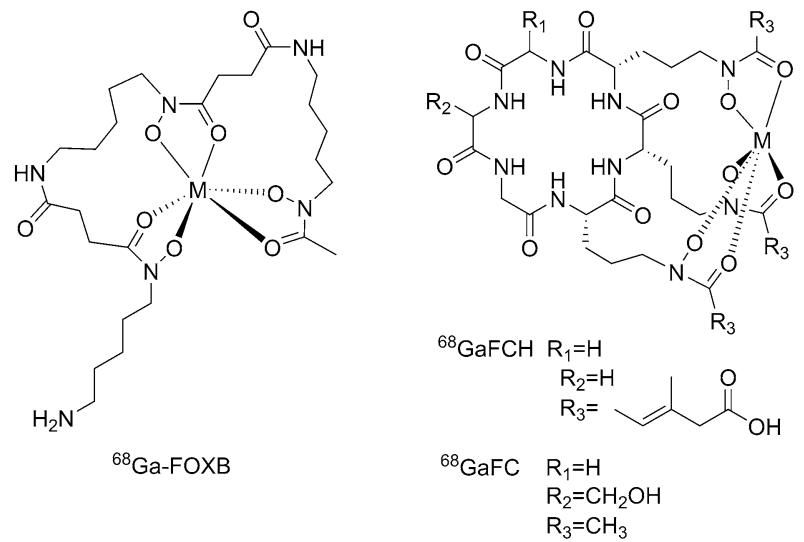

Scheme 8 Chemical structures of siderophores ${ }^{68} \mathrm{Ga}-\mathrm{TAFC},{ }^{68} \mathrm{Ga}-$ FUS, ${ }^{68} \mathrm{Ga}-\mathrm{FOXE},{ }^{68} \mathrm{Ga}-\mathrm{FOXB},{ }^{68} \mathrm{Ga}-\mathrm{FCH}$ and ${ }^{68} \mathrm{Ga}-\mathrm{FC} . M={ }^{68} \mathrm{Ga}$

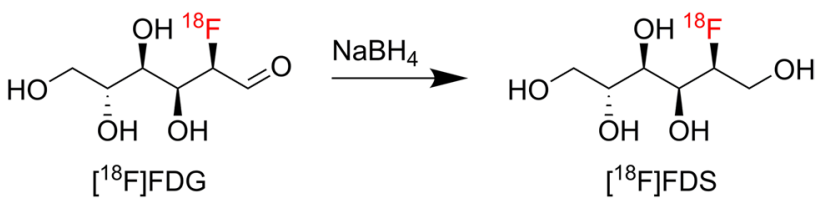

Scheme 9 Synthetic scheme of 2-Deoxy-2- $\left[{ }^{18} \mathrm{~F}\right]$-fluoro-D-sorbitol after reduction of 2-Deoxy-2-[ $\left.{ }^{18} \mathrm{~F}\right]$-fluoro-D-glucose using $\mathrm{NaBH}_{4}$

Following these promising initial findings, first biodistribution studies in healthy volunteers $(n=6)$ (Fig. 8) were undertaken, showing rapid renal clearance and the uptake of radioactivity in the colon and small intestines at later intervals [108]. With these promising results imaging studies of infections in patients are eagerly awaited [104, 109].

Alternatively, radiolabelled di- and polysaccharides such as maltose and maltodextrin, are an obvious imaging vehicle as they are specifically incorporated into multiple Gramnegative and Gram-positive bacterial membranes but not in mammalian cells $[110,111]$. The application of a ${ }^{99 \mathrm{~m}} \mathrm{Tc}-$ labelled hydroxypropyl- $B$-cyclodextrin $\left({ }^{99 \mathrm{~m}} \mathrm{Tc}-\mathrm{HP} \beta \mathrm{CD}\right)$ polysaccharide derivative (Scheme 10) as an infectionspecific tracer was demonstrated by Shukla et al.[112], where ${ }^{99 \mathrm{~m}} \mathrm{Tc}-\mathrm{HP} \beta \mathrm{CD}$ was mainly cleared via the kidneys 


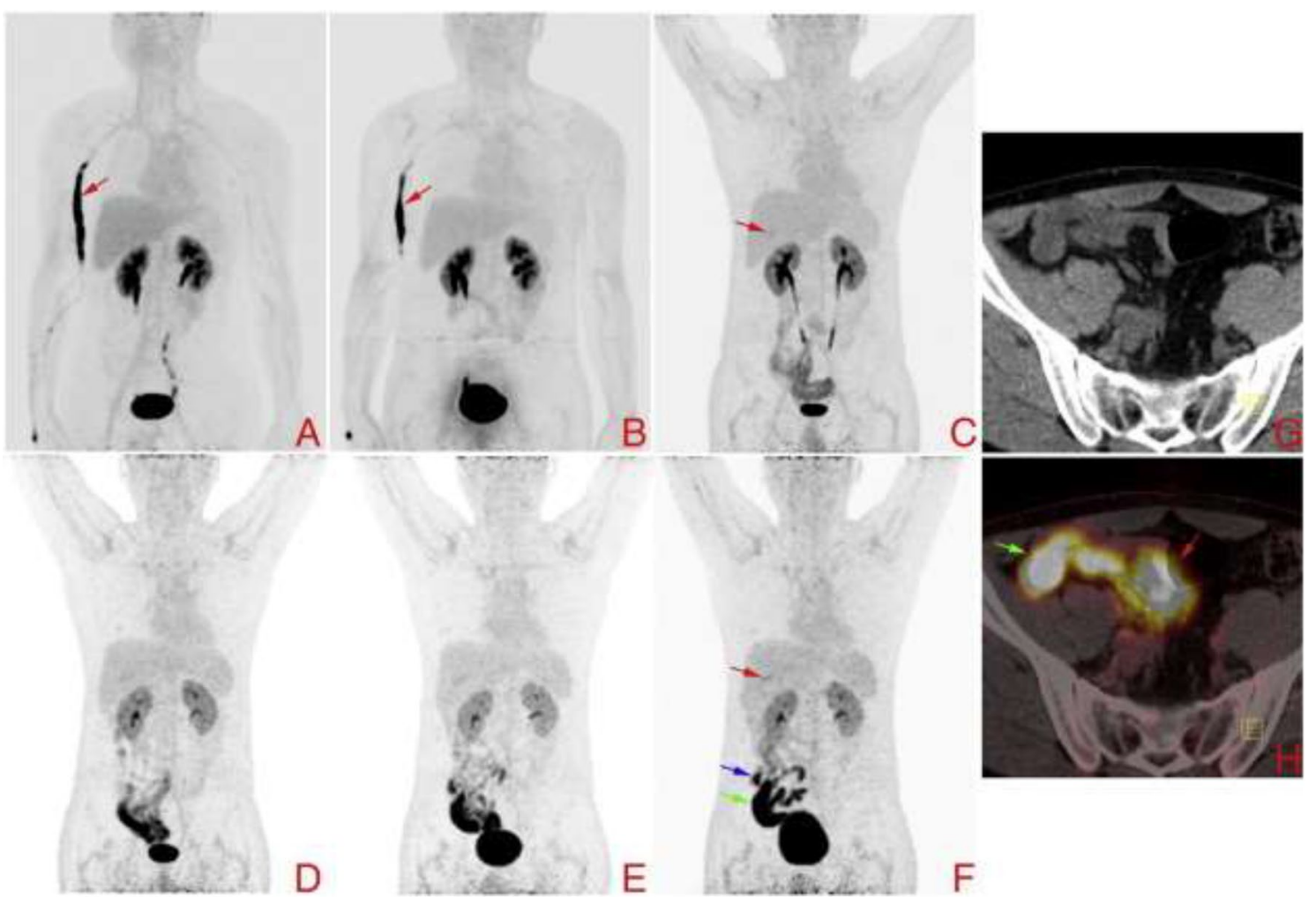

Fig. 8 Whole-body PET images of biodistribution and clearance of ${ }^{18} \mathrm{~F}$-FDS in a healthy volunteer. Whole-body PET images of ${ }^{18} \mathrm{~F}$ FDS uptake in a representative subject were acquired over 7 or 8 bed positions of varying duration. Whole body images were obtained during minutes 9-12 a, 48-60 b, 120-132 c, 180-191 d, 192-203 e and 204-214 f min post-injection. The probe was initially detected in vascular compartment, then rapidly distributed through extracellu-

and showed increased uptake in an infected knee after injection in one patient (Fig. 9). More recently, Gowrishankar et al. and Ning et al. demonstrated the use of the PET tracers 6- $\left[{ }^{18} \mathrm{~F}\right]$-fluoromaltose (Fig. 10) and 6- $\left[{ }^{18} \mathrm{~F}\right]$-fluoromaltohexaose (Scheme 10) in identifying infections with $E$. coli in mice with high sensitivity and specificity [113]. This tracer could discriminate between infectious sites with viable and dead bacteria. Similar results were reported for $6-\left[{ }^{18} \mathrm{~F}\right]-$ fluoromaltose and $6 "-\left[{ }^{18} \mathrm{~F}\right]$-fluoromaltotriose (Scheme 10, Fig. 11) both in mice and rats $[114,115]$. However, it has been reported that starch-reducing enzymes present in the blood reduced the serum stability of the tracers which in turn would limit its clinical use [116].

The synthesis of macromolecular peptidoglycan, a cell wall component that is present in both Gram-positive and Gram-negative bacteria, is another target for the specific imaging of bacterial infections. A single-stranded oligonucleotide [117], able to bind peptidoglycans with high specificity and sensitivity [118], was labelled with different radioisotopes and as such can be used for imaging bacterial and fungal infections [119, 120]. Imaging lar space, and finally was rapidly excreted through urine. a, b Linear activity (marked by red arrow) in frames is tracer accumulation in the vein, it is absorbed as time passes. c, f Faint gallbladder uptake was observed and is marked by red arrow, while the colon and small intestine are marked by blue and green arrows, respectively. $\mathbf{g}, \mathbf{h}$ Small intestine and bladder are marked by green and red arrows, respectively From: Yao S, et al. Nucl Med Biol. 2016;43(3):206-214

studies with the ${ }^{99 \mathrm{~m}} \mathrm{Tc}$-aptamer were carried out in thigh muscles of mice either infected with $S$. aureus, C. albicans, or with a sterile inflammation. Uptake in bacterial infections was low (abscess-to-muscle ratio $\approx 4$ ) but with higher ratios compared to the uptake in infections with $C$. albicans (abscess-to-muscle ratio $\approx 2.0$ ) or sterile inflammation (abscess-to-muscle ratio $\approx 1.2$ ) thus allowing discrimination of bacterial infections from fungal infections. Although these results are promising for future clinical use of this tracer the rapid degradation of the ${ }^{99 \mathrm{~m}} \mathrm{Tc}$-aptamer in blood poses a limiting factor [119].

\section{Imaging of bacterial surfaces and extra cellular structures}

Bacterial membranes and cell wall are different of structure compared to eukaryotic cells. In this chapter we describe the performance of tracers that specifically interact with specific bacterial structures. As cationic 

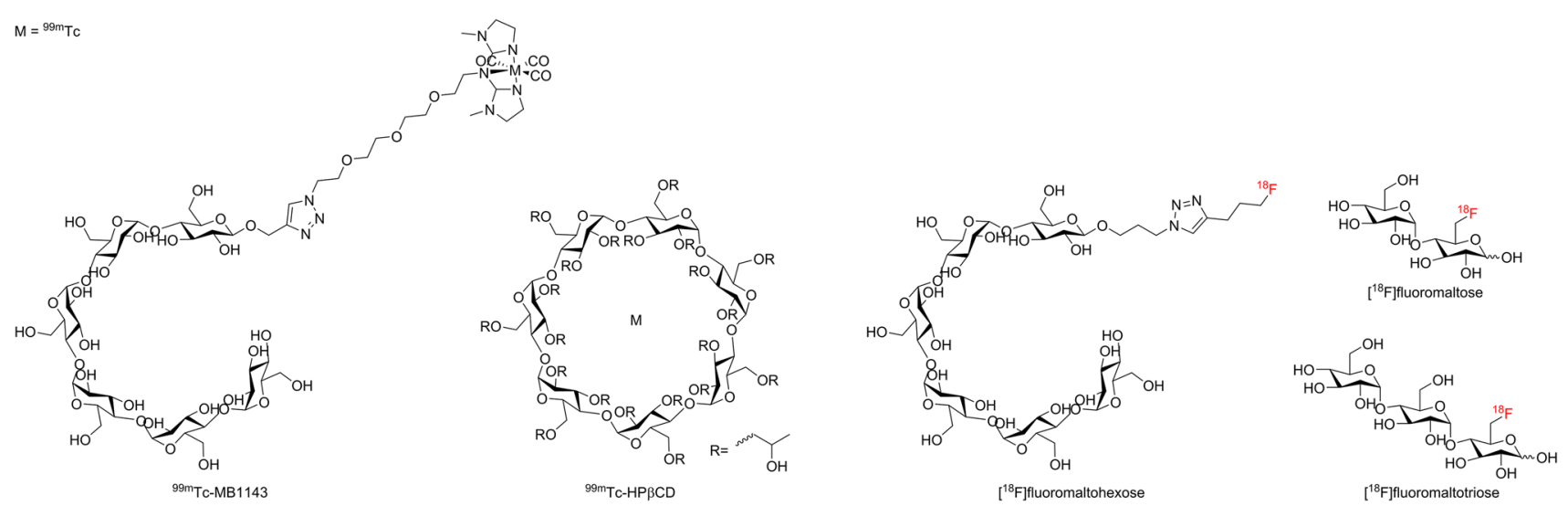

Scheme $10{ }^{99 \mathrm{~m}}$ Tc-labelled maltodextrin and -cyclodextrin (coordination unknown) derivatives used for the imaging of the carbohydrate metabolism. $M={ }^{99 \mathrm{~m}}$ Tc. ${ }^{18} \mathrm{~F}$-labelled oligosaccharides used for the imaging of the carbohydrate metabolism

Fig. $9{ }^{99 \mathrm{~m}} \mathrm{Tc}-\mathrm{HPbCD}$ images in human subjects with prosthesis infection From: Shukla $\mathrm{J}$, et al. Hell J Nucl Med. 2012;13(3):218-223
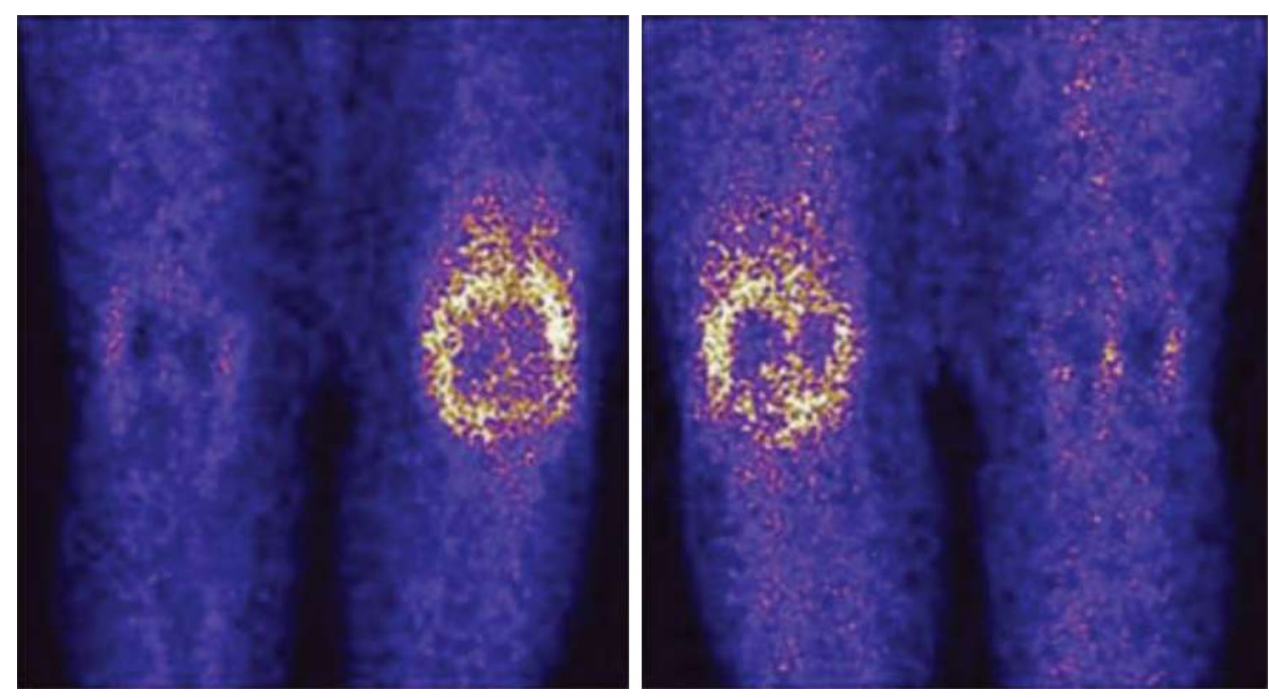

antimicrobial peptides interact with bacterial membranes as well, they were included in "Antibacterial tracers" because of their antimicrobial potential.

\section{Imaging of the biofilm}

Phage display library screening studies revealed a peptide $\left[{ }^{68} \mathrm{Ga}\right]$-DOTA-K-A9 with potency to bind to $S$. aureusgenerated biofilms [121]. After radiolabelling in vitro experiments revealed binding of $\left[{ }^{68} \mathrm{Ga}\right]-D O T A-K-A 9$ to staphylococcal bacteria, $S$. dysgalactiae and $P$. aeruginosa, [121]. In vivo studies in mice with the PET tracer $\left[{ }^{68} \mathrm{Ga}\right]-D O T A-K-A 9$ (Scheme 11) confirmed accumulation in subcutaneous staphylococcal infections (abscess-tobackground ratio $\approx 2.5$ ) but also showed uptake at sterile inflammatory sites (inflammation-to-background ratio $\approx$ 2.4). According to the authors, this observation was caused by a combination of local hyperaemia and vascular leakiness [122]. With the low specificity of $\left[{ }^{68} \mathrm{Ga}\right]-D O T A-K-$ A9 for $S$. aureus and the accumulation in sterile inflammatory sites, the clinical use for imaging of bacterial infections is limited.

\section{Imaging of the bacterial membrane}

The positively charged zinc-dipicolylamine (ZnDPA) moiety interacts with bacteria solely by electrostatic interactions and shows a selective affinity for the anionic cell membrane phospholipid phosphatidylserine. Various derivatives of ${ }^{111} \mathrm{In}-\mathrm{ZnDPA}$ (Scheme 12) have 


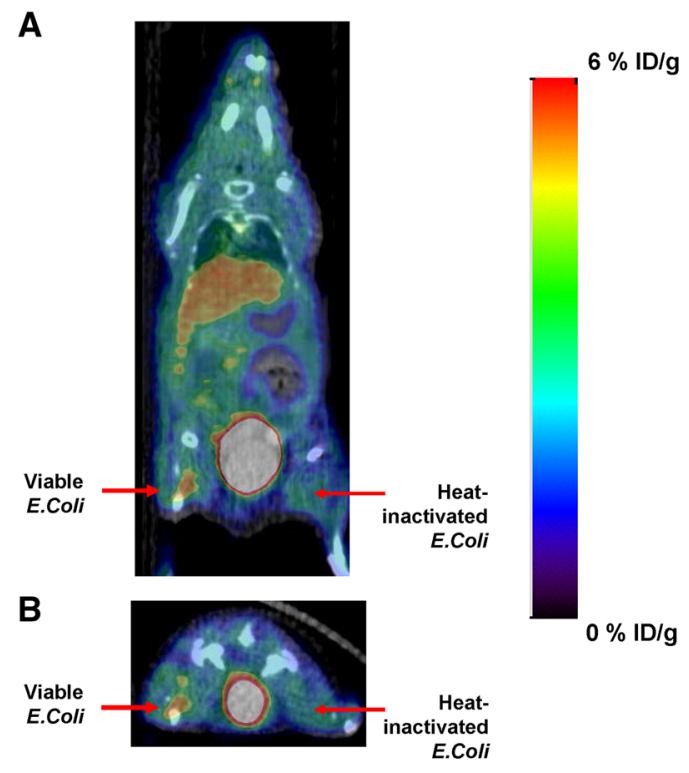

Fig. 10 Imaging with $6-\left[{ }^{18} \mathrm{~F}\right]$-fluoromaltose of viable bacteria. a A coronal slice from a PET/CT image of a mouse bearing $108 \mathrm{CFU}$ of viable bioluminescent $E$. coli on the right thigh (red arrow) and $108 \mathrm{CFU}$ of heat-inactivated E. coli on the left thigh, $1 \mathrm{~h}$ after tailvein injection of $7.4 \mathrm{MBq}$ of $6-\left[{ }^{18} \mathrm{~F}\right]$-fluoromaltose $\mathbf{b}$ A transverse
C
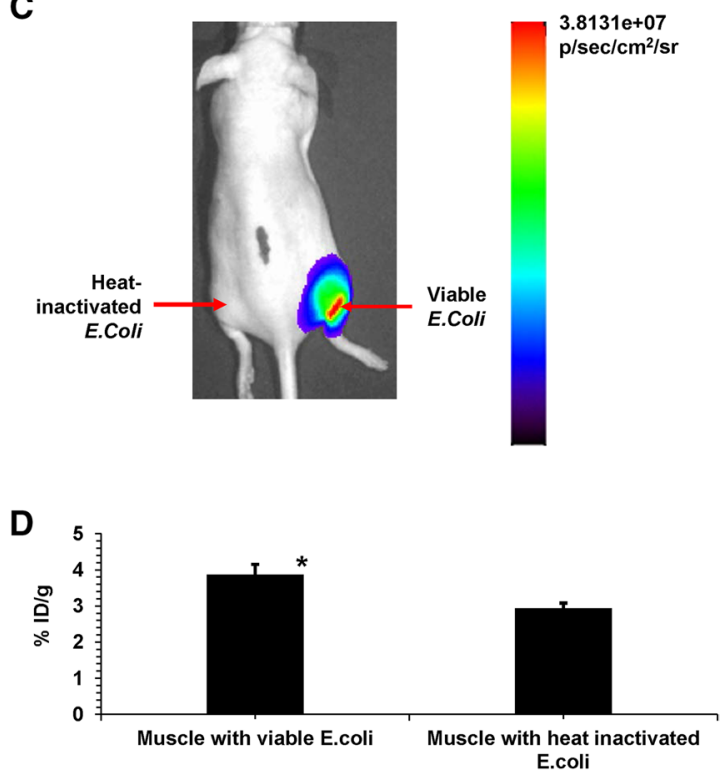

slice from the same mouse. c Bioluminescent image of the mouse as shown in (a). d ROI analysis from PET/CT scan of mice $(n=3)$. *Indicates statistical significance From: Gowrishankar G, et al. PloS one. 2014;9(9):e10795
Fig. 11 Evaluation of $6^{\prime \prime 18} \mathrm{~F}$-fluoromaltotriose in $P$. aeruginosa wound infection model. a Bioluminescence images of CD1 mice bearing $P$. aeruginosa-infected wound (left) and control mice (right). b Sagittal slices from small-animal PET/CT scan of same mice $1 \mathrm{~h}$ after intravenous administration of $6 "{ }^{\prime 18} \mathrm{~F}$-fluoromaltotriose From: Gowrishankar G, et al. J Nucl Med. 2017;58(10):1679_ 1684

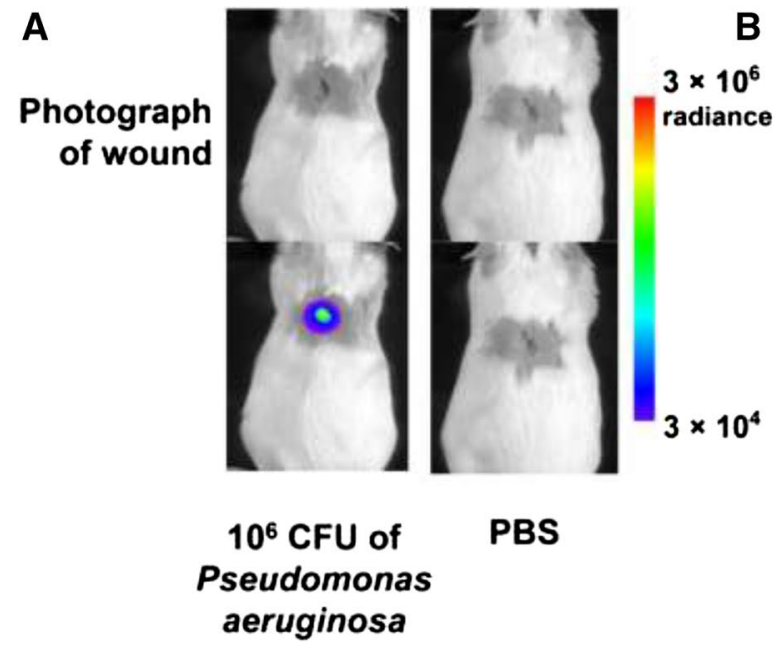

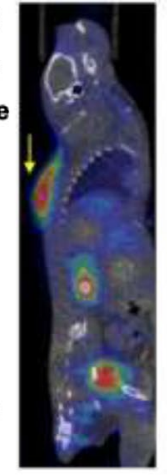

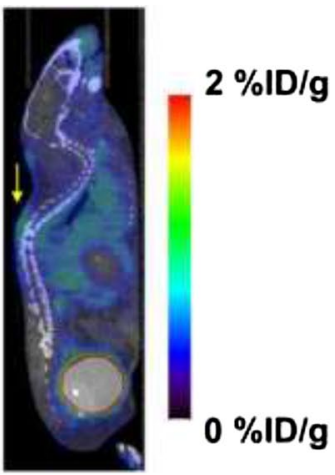

\section{Sagittal view (microPET/CT)}

been developed [123, 124] and ZnDPA tracers accumulated specifically at sites of bacterial infections [123]. In a thigh muscle model in mice infected with $S$. pyogenes ${ }^{111}$ In-DOTA-biotin/SA/biotin-ZnDPA accumulated 2.eightfold higher in sites with infections than in sterile inflammatory sites. For ZnDPA- $\left[{ }^{111} \mathrm{In}\right]-\mathrm{DTPA}$ and ZnDPA[ $\left.{ }^{111} \mathrm{In}\right]$-DOTA, each with a single ZnDPA targeting unit, and a divalent tracer, Bis(ZnDPA)-[ ${ }^{111}$ In]-DTPA abscessto-muscle ratios between 2.4 and 6.2 for the divalent one was reported in $S$. pyogenes infected thigh muscles. Clearance of the divalent tracer from the bloodstream was, compared to monovalent tracers, slow and mainly through the liver, gall bladder and intestines. Because of exposure of negatively charged molecules however, in other studies ${ }^{99 \mathrm{~m}}$ Tc-HYNIC-DPA was shown to image cell death in vivo [123], cardiomyocyte apoptosis [125], mammary and prostate tumours [126], and more recently Leishmania major parasites [127]. Because of the electrostatic interaction with charged groups within tumour cell membranes and necrotic tissues limits its use for specific imaging of infections [128]. 
Scheme 11 Chemical structure of the $\left[{ }^{68} \mathrm{Ga}\right]$-DOTA-K-A9 radiolabelled peptide
Scheme 12 Chemical structures of $\mathrm{ZnDPA}$ derivatives when conjugating to DTPA or DOTA to enable labelling with ${ }^{111}$ In

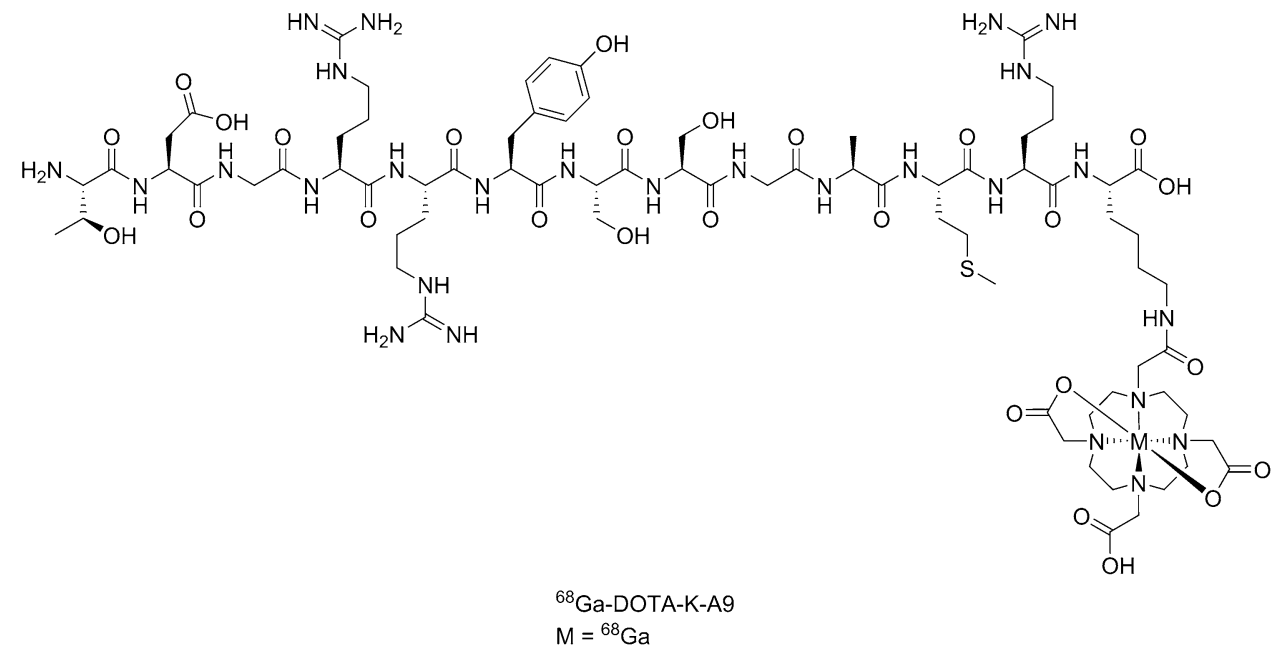

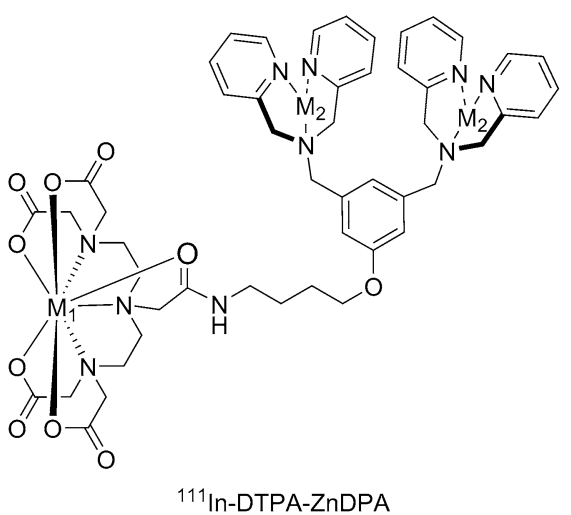

$\mathrm{M}_{1}={ }^{111} \ln$ $\mathrm{M}_{2}=\mathrm{Zn}^{2+}$

$$
\text { DPA] }
$$

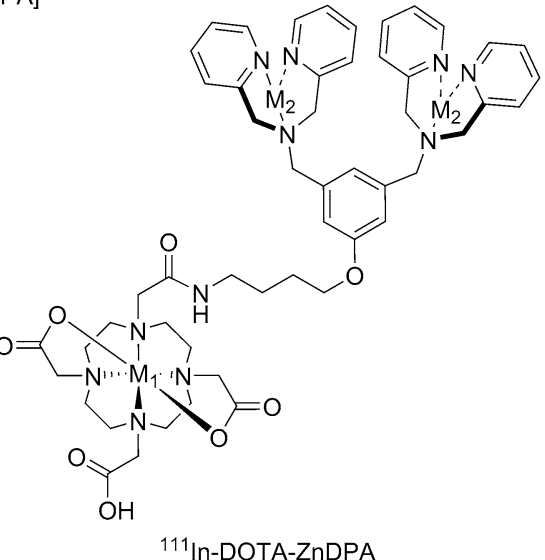

\section{Summary}

Newly developed pre-clinical SPECT and PET tracers, are showing promising results in distinguishing between sterile inflammation, bacterially induced infections, or cancer. Some of these tracers deliver, fast and accurate diagnosis of bacterial infections which is fundamental to initialise specific and efficient antimicrobial treatment and as such combat antimicrobial resistance. An overview of the proposed properties for these molecular imaging agents that can specifically target bacteria are shown in Table 2 .

Therefore, many efforts have been made in recent years to discover and develop novel radioactive bacteria-specific tracers as we discussed in this review, of which the most promising are depicted in Table 3. A limitation in reviewing tracer development for imaging infections is the great 
diversity in radiochemistry, animal models, the pathogens used, and the size of the inoculum. These factors limit the ability to draw conclusions or to make a direct comparison about performance in imaging of bacterial infections between the various tracers. In our view, the highest translational potential lies with tracers that are specific to target the pathogens: e.g., ${ }^{99 \mathrm{~m}} \mathrm{Tc}-$ and ${ }^{68} \mathrm{Ga}$-labelled $\mathrm{UBI}_{29-41}$, ${ }^{99 \mathrm{~m}} \mathrm{Tc}$-vancomycin, $m$ - $\left[{ }^{18} \mathrm{~F}\right]$-fluoro-PABA, [methyl- ${ }^{11} \mathrm{C}$ ]$D$-methionine, $\left[{ }^{18} \mathrm{~F}\right]$-FDS, $\left[{ }^{18} \mathrm{~F}\right]$-maltohexaose and $[18 \mathrm{~F}]-$ maltotriose. An encouraging note is that some of these tracers have already been successfully evaluated and compared with commonly used tracers in clinical settings [129].

\section{Future directions}

Altogether, pre-clinical development and evaluation of radioactive labelled bacteria-imaging tracers for SPECT/ PET imaging is still in progress and shows improvements in specificity and sensitivity. As we described in this review, for radiolabelled bacteria imaging tracers the issue of differentiating infections from other pathologies remains the biggest hurdle to take. Fortunately, the first results show great promise and some of these tracers are recently evaluated in clinical studies. Data concerning specificity, sensitivity, and safety assessments including toxicity and dosimetric issues are eagerly awaited.

Despite the enormous progress in the development of bacteria-specific radiotracers, it must be kept in mind that none of the previously described tracers is able to discriminate between antibiotic sensitive or -resistant bacterial strains. Therefore, more research is required to bridge the gap between imaging and molecular techniques for detection of different bacterial species and the resistance properties, especially for bacteria in chronic or recurrent infections. This approach may have the greatest potential to increase the contribution of clinical diagnostics to personalised antimicrobial therapy in the near future. In relation to infection imaging in less developed countries there is an urgent need for specific imaging at low-costs. As nearly $2 / 3$ of the world's population does not have access to any radiological services, with the development of low-tech handheld imaging modalities and specific bacterial infection imaging tracers, may effectively assist diagnosing infections the field. Widespread use of smartphones and tablets throughout developing countries promotes to use in combination with wireless and portables technologies [130-132]. This, as a result of misdiagnosis of infections and other tropical diseases, to limit the overuse of antibiotics which leads to increasing rates of drug resistance [13].

In the last decade, fluorescently labelled imaging agents have attracted enormous attention [133] and more recently hybrid tracers which include both a radioactive and optical reporter molecule were introduced [134]. Applying both techniques for dedicated infection imaging may be an advantage as bacteria can be localised and quantified by nuclear imaging modalities such as SPECT and PET, and areas may be cleaned based on optical
Table 2 Requirements for an optimal tracer for imaging bacterial infections Adapted and modified from Gemmel et al. Future diagnostic agents, Seminars in Nuclear Medicine 39(1) (2009) 11-26

\begin{tabular}{|c|c|}
\hline Property & Results \\
\hline High affinity for and strong binding to bacteria & $\begin{array}{l}\text { Total body imaging of disseminated and colo- } \\
\text { nised pathogens } \\
\text { Specific for bacterial infections } \\
\text { Rapid localisation } \\
\text { High sensitivity } \\
\text { High resolution }\end{array}$ \\
\hline Preferential biodistribution & $\begin{array}{l}\text { Fast renal clearance from non-infected tissues } \\
\text { High target-to-background ratios }\end{array}$ \\
\hline Proportional uptake of the radiotracer & $\begin{array}{l}\text { Imaging the degree of infection } \\
\text { Monitoring effects of antimicrobial therapy }\end{array}$ \\
\hline Absence of side effects & $\begin{array}{l}\text { No toxicity } \\
\text { Stable chemistry } \\
\text { No immunological responses } \\
\text { Safe use } \\
\text { Acceptable radiation dosimetry } \\
\text { Allowing repeated injections }\end{array}$ \\
\hline Feasibility & $\begin{array}{l}\text { Low costs for production and tracer preparation } \\
\text { Easy to use kit formulation }\end{array}$ \\
\hline Utility & $\begin{array}{l}\text { Real-time imaging } \\
\text { Possibility for guided biopsy/wound cleaning } \\
\text { Tracer optimisation or modification for therapy } \\
\text { Applicable in controlled human infections } \\
\text { (CHI) for vaccine development }\end{array}$ \\
\hline
\end{tabular}




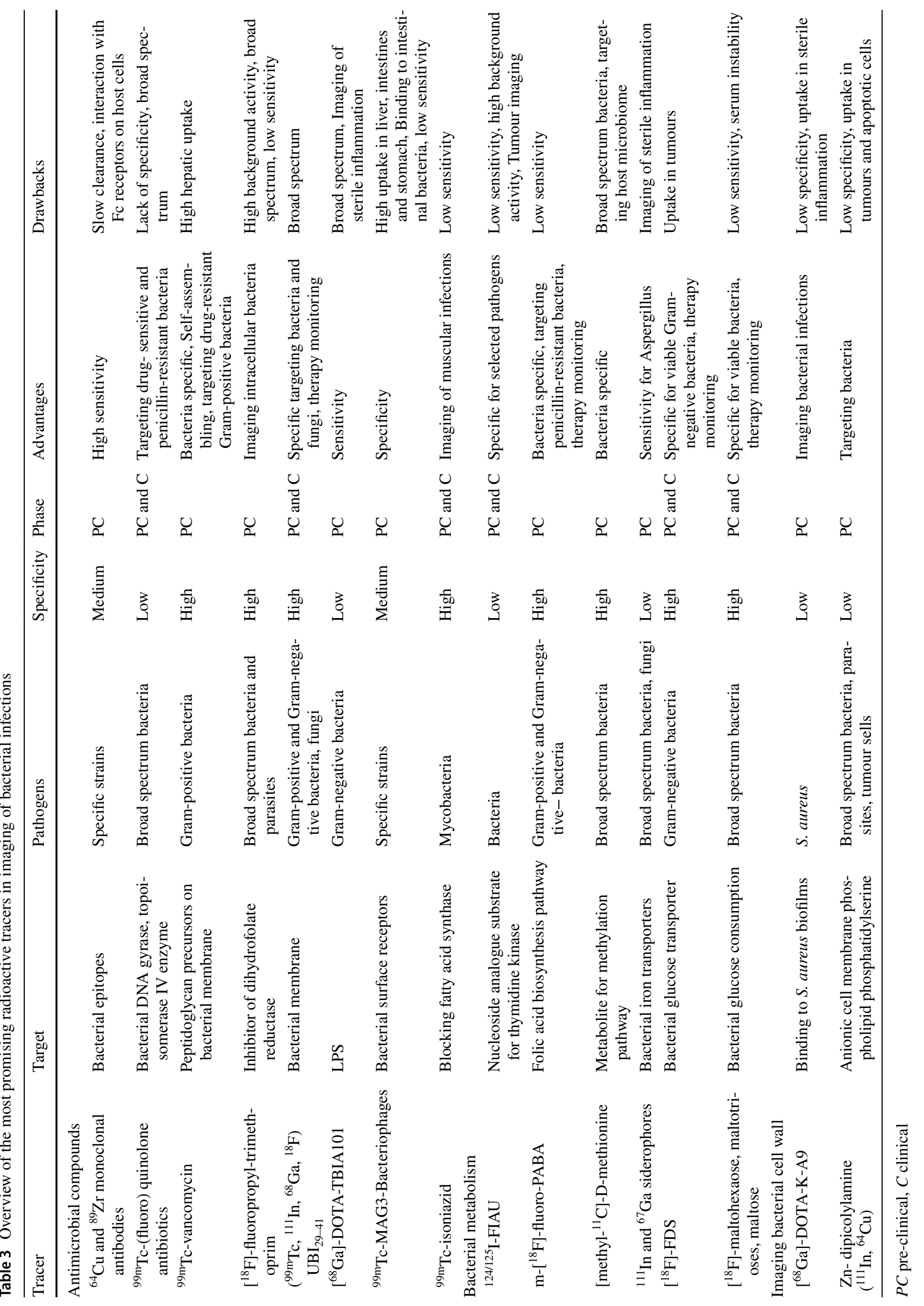


real-life fluorescence imaging. Hybrid tracers such based on $\mathrm{UBI}_{29-41}$ are specifically designed to facilitate such transitions [73].

Acknowledgements The research leading to these results was funded with grants from the Netherlands Organization for Scientific Research (VIDI-grant - STW BGT11272), Meta Roestenberg was supported by a VENI grant from ZONMW and a Gisela Thier fellowship from the LUMC.

\section{Compliance with ethical standards}

Competing interests The authors have declared that no competing interest exists.

Ethical approval In the selected literature those were only included if all procedures followed were in accordance with the ethical standards of the responsible committee on human experimentation (institutional and national) and with the Helsinki Declaration of 1975, as revised in 2008 .

Informed consent Informed consent was obtained from all patients for being included in these studies.

OpenAccess This article is distributed under the terms of the Creative Commons Attribution 4.0 International License (http://creativeco mmons.org/licenses/by/4.0/), which permits unrestricted use, distribution, and reproduction in any medium, provided you give appropriate credit to the original author(s) and the source, provide a link to the Creative Commons license, and indicate if changes were made.

\section{References}

1. Li B, Webster TJ (2018) Bacteria antibiotic resistance: New challenges and opportunities for implant-associated orthopedic infections. J Orthop Res. 36(1):22-32

2. Palestro CJ (2014) Nuclear medicine and the failed joint replacement: Past, present, and future. World J Radiol. 6(7):446-458

3. Becker W, Meller J (2001) The role of nuclear medicine in infection and inflammation. Lancet Infect Dis. 1(5):326-333

4. Gemmel F, Dumarey N, Welling M (2009) Future diagnostic agents. Semin Nucl Med. 39(1):11-26

5. Rak M, Barlič-Maganja D, Kavčič M, Trebše R, Cőr A (2013) Comparison of molecular and culture method in diagnosis of prosthetic joint infection. FEMS Microbiol Lett. 343(1):42-48

6. Kothari A, Morgan M, Haake Da. Emerging technologies for rapid identification of bloodstream pathogens. Clin Infect Dis. 2014;59(2):272-8.

7. Potgieter M, Bester J, Kell DB, Pretorius E. The dormant blood microbiome in chronic, inflammatory diseases. FEMS Microbiol Rev. 2015 39(4):567-595.

8. Mohajer MA, Darouiche RO (2014) The expanding horizon of prosthetic joint infections. J Appl Biomater Funct Mater. 12(1):1-12

9. Gemmel F, Van den Wyngaert H, Love C, Welling MM, Gemmel P, Palestro CJ (2012) Prosthetic joint infections: radionuclide state-of-the-art imaging. Eur J Nucl Med Mol Imaging. 39(5):892-909
10. Eggleston H, Panizzi P (2014) Molecular imaging of bacterial infections in vivo: the discrimination of infection from inflammation. Informatics (MDPI). 1(1):72-99

11. Gemmel F, Dumarey N, Palestro CJ (2006) Radionuclide imaging of spinal infections. Eur J Nucl Med Mol Imagin. 33(10):1226-1237

12. Ordonez AA, Jain SK (2018) Pathogen-specific bacterial imaging in nuclear medicine. Semin Nucl Med. 48(2):182-194

13. Win AZ (2016) What can nuclear medicine physicians and radiologists do for global health? WorldJ Nucl Med. 15(1):1-2

14. Bunschoten A, Welling MM, Tennaat MF, Sathekge M, van Leeuwen FWB (2013) Development and prospects of dedicated tracers for the molecular imaging of bacterial infections. Bioconjugate Chem. 24(12):1971-1989

15. Salmanoglu E, Kim S, Thakur ML (2018) Currently available radiopharmaceuticals for imaging infection and the holy grail. Semin Nucl Med. 48(2):86-99

16. Velikyan I (2018) Prospective of 68Ga radionuclide contribution to the development of imaging agents for infection and inflammation. Contrast Media Mol Imaging. 2018:24

17. Wareham D, Michael J, Das S (2005) Advances in Bacterial Specific Imaging. Braz Arch Biol Technol. 48(2):145-152

18. Heuker M, Gomes A, van Dijl JM, van Dam GM, Friedrich AW, Sinha B et al (2016) Preclinical studies and prospective clinical applications for bacteria-targeted imaging: the future is bright. Clin Transl Imaging. 4(4):253-264

19. Lazzeri E (2016) Systematic review of in vivo microorganisms imaging with labeled vitamins, bacteriophages and oligomers. Clin Transl Imaging. 4(4):265-272

20. Sasser TA, Avermaete AEV, White A, Chapman S, Johnson JR, Avermaete TV et al (2013) Bacterial infection probes and imaging strategies in clinical nuclear medicine and preclinical molecular imaging. Curr Top Med Chem. 13(4):479-487

21. van Oosten M, Hahn M, Crane LMA, Pleijhuis RG, Francis KP, van Dijl JM et al (2015) Targeted imaging of bacterial infections: advances, hurdles and hopes. FEMS Microbiol Rev. 39(6):892-916

22. Pinkston KL, Singh KV, Gao P, Wilganowski N, Robinson H, Ghosh S et al (2014) Targeting pili in enterococcal pathogenesis. Infect Immun. 82(4):1540-1547

23. Wiehr S, Warnke P, Rolle AM, Schutz M, Oberhettinger P, Kohlhofer U et al (2016) New pathogen-specific immunoPET/ MR tracer for molecular imaging of a systemic bacterial infection. Oncotarget. 7(10):10990-11001

24. Romero Pastrana F, Thompson JM, Heuker M, Hoekstra H, Dillen CA, Ortines RV et al (2018) Noninvasive optical and nuclear imaging of Staphylococcus-specific infection with a human monoclonal antibody-based probe. Virulence. 9(1):262-272

25. Rubin RH, Young LS, Hansen WP, Nedelman M, Wilkinson $\mathrm{R}$, Nelles MJ et al (1988) Specific and nonspecific imaging of localized Fisher immunotype 1 Pseudomonas aeruginosa infection with radiolabeled monoclonal antibody. J Nucl Med. 29(5):651-656

26. Pickett JE, Thompson JM, Sadowska A, Tkaczyk C, Sellman BR, Minola A et al (2018) Molecularly specific detection of bacterial lipoteichoic acid for diagnosis of prosthetic joint infection of the bone. Bone Res. 6:13

27. Welling M, Feitsma HIJ, Calame W, Ensing GJ, Wim G, Pauwels EKJ et al (1994) Optimized localization of bacterial infections with technetium-99m labelled human immunoglobulin after protein charge selection. Eur J Nucl Med. 21(10):1135-1140

28. Calame W, Welling M, Feitsma HIJ, Goedemans WT, Pauwels EKJ (1995) Contribution of phagocytic cells and bacteria to the accumulation of technetium-99m labelled polyclonal 
human immunoglobulin at sites of inflammation. Eur J Nucl Med. 22(7):638-644

29. Kniess T, Laube M, Wüst F, Pietzsch J (2017) Technetium$99 \mathrm{~m}$ based small molecule radiopharmaceuticals and radiotracers targeting inflammation and infection. Dalton $\mathrm{T}$. 46(42):14435-14451

30. Britton KE, Vinjamuri S, Hall AV, Solanki K, Siraj QH, Bomanji J et al (1997) Clinical evaluation of technetium-99m infecton for the localisation of bacterial infection. Eur J Nucl Med. 24(5):553-556

31. Britton KE, Wareham DW, Das SS, Solanki KK, Amaral $\mathrm{H}$, Bhatnagar A et al (2002) Imaging bacterial infection with (99m)Tc-ciprofloxacin (Infecton). J Clin Pathol 55(11):817-823

32. Salouti M, Fazli A (2013) Infectious foci imaging with targeting radiopharmaceuticals in nuclear medicine. In: Okechukwu Felix E, editor. Medical Imaging in Clinical Practice. InTechOpen Limited, London

33. Yue B, Tang T (2015) The use of nuclear imaging for the diagnosis of periprosthetic infection after knee and hip arthroplasties. Nucl Med Commun. 36(4):305-311

34. Welling M, Stokkel M, Balter J, Sarda-Mantel L, Meulemans A, Le Guludec D (2008) The many roads to infection imaging. Eur J Nucl Med Mol Imaging. 35(4):848-849

35. Welling MM, Nibbering PH, Paulusma-Annema A, Hiemstra PS, Pauwels EKJ, Calame W (2000) Imaging of bacterial infections with Tc-99m-labeled human neutrophil peptide-1 - Reply. J Nucl Med. 41(12):2100-2102

36. LeMaire SA, Zhang L, Luo W, et al. (2018) Effect of ciprofloxacin on susceptibility to aortic dissection and rupture in mice. JAMA Surg. 153(9):e181804.

37. Mehlhorn AJ, Brown DA (2007) Safety concerns with fluoroquinolones. Annal Pharmacother. 41(11):1859-1866

38. WHO updates Essential Medicines List with new advice on use of antibiotics, and adds medicines for hepatitis C, HIV, tuberculosis and cancer [News Release]. WHO, Geneva.

39. Shah SQ, Khan AU, Khan MR (2011) 99mTc(CO)3-Garenoxacin dithiocarbamate synthesis and biological evolution in rats infected with multiresistant Staphylococcus aureus and penicillin-resistant Streptococci. J Radioanal Nucl Chem. 288(1):171-176

40. Shah SQ, Khan MR, Ali SM (2011) Radiosynthesis of $99 \mathrm{mTc}(\mathrm{CO}) 3$-clinafloxacin dithiocarbamate and its biological evaluation as a potential staphylococcus aureus infection radiotracer. Nucl Med Mol Imag. 45(4):248-254

41. Shah SQ, Khan MR (2011) $99 \mathrm{mTcN}$-gatifloxacin dithiocarbamate complex: a novel multi-drug-resistance Streptococcus pneumoniae (MRSP) infection radiotracer. J Radioanal Nucl Chem. 289(3):903-908

42. Roohi S, Mushtaq A, Malik Salman A (2005) Synthesis and biodistribution of $99 \mathrm{mTc}$-Vancomycin in a model of bacterial infection. Radiochim Acta. 93(7):415-418

43. Vito A, Alarabi H, Czorny S, Beiraghi O, Kent J, Janzen N, et al. (2016) A 99mTc-labelled tetrazine for bioorthogonal chemistry. synthesis and biodistribution studies with small molecule transcyclooctene derivatives. PLoS One 11(12):e0167425.

44. Neu HC GT (1996) Antimicrobial chemotherapy. In: Baron S, editor. Medical Microbiology. 4 ed. Galveston (TX): University of Texas Medical Branch at Galveston

45. van Oosten M, Schäfer T, Gazendam JaC, Ohlsen K, Tsompanidou E, de Goffau MC, et al. (2013) Real-time in vivo imaging of invasive- and biomaterial-associated bacterial infections using fluorescently labelled vancomycin. Nature Commun 4:2584

46. Sellmyer MA, Lee I, Hou C, Weng CC, Li S, Lieberman BP et al (2017) Bacterial infection imaging with [(18)F]fluoropropyl-trimethoprim. Proc Natl Acad Sci U S A. 114(31):8372-8377
47. Singh AK, Verma J, Bhatnager A, Sen S (2003) Tc-99m Isoniazid: A specific agent for diagnosis of tuberculosis. World J Nucl Med. 2(4):292-305

48. Hazari PP, Chuttani K, Kumar N, Mathur R, Sharma R, Singh B et al (2009) Synthesis and biological evaluation of isonicotinic acid hydrazide conjugated with diethyelenetriaminepentaacetic acid for infection imaging. Open Nucl Med J. 1(1):33-42

49. McPhee JB, Hancock RE (2005) Function and therapeutic potential of host defence peptides. J Pept Sci. 11(11):677-687

50. Brender JR, McHenry AJ, Ramamoorthy A (2012) Does cholesterol play a role in the bacterial selectivity of antimicrobial peptides? Front Immunol. 3:195

51. Glukhov E, Stark M, Burrows LL, Deber CM (2005) Basis for selectivity of cationic antimicrobial peptides for bacterial versus mammalian membranes. J Biol Chem. 280(40):33960-33967

52. Welling MM, Paulusma-Annema A, Balter HS, Pauwels EKJ, Nibbering PH (2000) Technetium-99m labelled antimicrobial peptides discriminate between bacterial infections and sterile inflammations. Eur J Nucl Med. 27(3):292-301

53. Welling MM, Lupetti A, Balter HS, Lanzzeri S, Souto B, Rey AM et al (2001) 99mTc-labeled antimicrobial peptides for detection of bacterial and Candida albicans infections. J Nucl Med. 42(5):788-794

54. Brouwer CPJM, Sarda-Mantel L, Meulemans A, Le Guludec D, Welling MM (2008) The use of technetium-99m radiolabeled human antimicrobial peptides for infection specific imaging. Mini-Rev Med Chem. 8(10):1039-1052

55. Ferro-Flores G, Avila-Rodríguez MA, García-Pérez FO (2016) Imaging of bacteria with radiolabeled ubiquicidin by SPECT and PET techniques. Clin Transl Imag. 4(3):175-182

56. Welling MM, Ferro-flores G, Pirmettis I, Brouwer CPJM (2009) Current status of imaging infections with radiolabeled anti-infective agents. Antiinfect Agents Med Chem. 8(3):272-287

57. Gandomkar M, Najafi R, Shafiei M, Mazidi M, Goudarzi M, Mirfallah S et al (2009) Clinical evaluation of antimicrobial peptide [(99m)Tc/Tricine/HYNIC(0)]ubiquicidin 29-41 as a humanspecific infection imaging agent. Nucl Med Biol. 36(2):199-205

58. Vilche M, Reyes AL, Vasilskis E, Oliver P, Balter H, Engler H (2016) 68Ga-NOTA-UBI-29-41 as a pet tracer for detection of bacterial infection. J Nucl Med. 57(4):622-627

59. Mukherjee A, Bhatt J, Shinto A, Korde A, Kumar M, Kamaleshwaran K et al (2018) 68Ga-NOTA-ubiquicidin fragment for PET imaging of infection: From bench to bedside. J Pharm Biomed Anal. 159:245-251

60. Ebenhan T, Zeevaart JR, Venter JD, Govender T, Kruger GH, Jarvis NV et al (2014) Preclinical evaluation of Ga-68-labeled 1,4,7-Triazacyclononane-1,4,7-Triacetic acid-ubiquicidin as a radioligand for PET infection imaging. J Nucl Med. 55(2):308-314

61. Ebenhan T, Gheysens O, Kruger HG, Zeevaart JR, Sathekge MM. Antimicrobial peptides: Their role as infection-selective tracers for molecular imaging. BioMed Res Int. 2014;2014:867381-.

62. Bhatt J, Mukherjee A, Shinto A, Koramadai Karuppusamy K, Korde A, Kumar M et al (2018) Gallium-68 labeled Ubiquicidin derived octapeptide as a potential infection imaging agent. Nucl Med Biol. 62-63:47-53

63. Lupetti A, Welling MM, Mazzi U, Nibbering PH, Pauwels EKJ (2002) Technetium-99m labelled fluconazole and antimicrobial peptides for imaging of Candida albicans and Aspergillus fumigatus infections. Eur J Nucl Med Mol Imaging. 29(5):674-679

64. de Murphy CA, Gemmel F, Balter J (2010) Clinical trial of specific imaging of infections. Nucl Med Commun. 31(8):726-733

65. Ostovar A, Assadi M, Vahdat K, Nabipour I, Javadi H, Eftekhari M (2013) A pooled analysis of diagnostic value of Tc99m-ubiquicidin (ubi) scintigraphy in detection of an infectious process. Clin Nucl Med. 38(6):413-416 
66. Ocampo IZ, de Queiroz Souza Passos P, Ramirez de Carvalho L, Lira da Cruz CA, Esteves-Pedro NM, Medeiros da Silva F, et al. (2016) In vitro cytotoxic and genotoxic evaluation of peptides used in nuclear medicine (DOTATATE and Ubiquicidin29-41) in CHO-K1 cells. Cytotechnology 68(6):2301-10

67. Carrasco-Hernandez J, SolÂs-Lara H, Altamirano-Ley J, Avila-Rodriguez M (2016) Measured human dosimetry of 68Ga-DOTA-UBI 29-41, a potential tracer for imaging bacterial infection processes. J Nucl Med. 57(supplement 2):1020

68. Melendez-Alafort L, Rodriguez-Cortes J, Ferro-Flores G, De Murphy CA, Herrera-Rodriguez R, Mitsoura E et al (2004) Biokinetics of Tc-99m-UBI 29-41 in humans. Nucl Med Biol. 31(3):373-379

69. Ebenhan T, Sathekge MM, Lengana T, Koole M, Gheysens O, Govender T et al (2018) (68)Ga-NOTA-functionalized ubiquicidin: cytotoxicity, biodistribution, radiation dosimetry, and first-in-human PET/CT Imaging of infections. J Nucl Med. 59(2):334-339

70. Welling MM, Korsak A, Gorska B, Oliver P, Mikolajczak R, Balter HS et al (2005) Kit with technetium-99m labelled antimicrobial peptide UBI 29-41 for specific infection detection. J Label Compd Radiopharm. 48(9):683-691

71. Ferro-Flores G, de Murphy CA, Palomares-Rodriguez P, Melendez-Alafort L, Pedraza-Lopez M (2005) Kit for instant Tc-99m labeling of the antimicrobial peptide ubiquicidin 29-41. J Radioanal Nucl Chem. 266(2):307-311

72. Arjun C, Mukherjee A, Bhatt J, Chaudhari P, Repaka KM, Venkatesh M et al (2016) Studies on batch formulation of a kit for the preparation of the 99mTc-Ubiquicidin (29-41): An infection imaging agent. Appl Radiat Isot. 107:8-12

73. Welling MM, Bunschoten A, Kuil J, Nelissen RGHH, Beekman FJ, Buckle T et al (2015) Development of a hybrid tracer for SPECT and optical imaging of bacterial infections. Bioconjug Chem. 26(5):839-849

74. Rieffel J, Chitgupi U, Lovell JF (2015) Recent advances in higher-order, multimodal, biomedical imaging agents. Small. 11(35):4445-4461

75. Criscione JM, Dobrucki LW, Zhuang ZW, Papademetris X, Simons M, Sinusas AJ et al (2011) Development and application of a multimodal contrast agent for SPECT/CT hybrid imaging. Bioconjug Chem. 22(9):1784-1792

76. Brouwer CPJM, Bogaards SJP, Wulferink M, Velders MP, Welling MM (2006) Synthetic peptides derived from human antimicrobial peptide ubiquicidin accumulate at sites of infections and eradicate (multi-drug resistant) Staphylococcus aureus in mice. Peptides 27(11):2585-2591

77. Brouwer CPJM, Rahman M, Welling MM (2011) Discovery and development of a synthetic peptide derived from lactoferrin for clinical use. Peptides 32(9):1953-1963

78. Welling MM, Brouwer CPJM, van 't Hof W, Veerman ECI, Amerongen AVN (2007) Histatin-derived monomeric and dimeric synthetic peptides show strong bactericidal activity towards multidrug-resistant Staphylococcus aureus in vivo. Antimicrob Agent Chemother 51(9):3416-9.

79. Dutta J, Baijnath S, Somboro AM, Nagiah S, Albericio F, de la Torre BG et al (2017) Synthesis, in vitro evaluation, and (68) Ga-radiolabeling of CDP1 toward PET/CT imaging of bacterial infection. Chem Biol Drug Des. 90(4):572-579

80. Narayanaswamy VK, Albericio F, Coovadia YM, Kruger HG, Maguire GEM, Pillay M et al (2011) Total synthesis of a depsidomycin analogue by convergent solid-phase peptide synthesis and macrolactonization strategy for antitubercular activity. Pept Sci. 17(10):683-689

81. Mokaleng BB, Ebenhan T, Ramesh S, Govender T, Kruger HG, Parboosing R et al (2015) Synthesis, 68Ga-radiolabeling, and preliminary in vivo assessment of a depsipeptide-derived compound as a potential PET/CT infection imaging agent. Biomed Res Int. 2015:284354

82. Ebenhan T, Mokaleng B, Venter J, Kruger H, Zeevaart J, Sathekge M (2017) Preclinical assessment of a 68ga-dota-functionalized depsipeptide as a radiodiagnostic infection imaging agent. Molecules 22(9):1403

83. Drulis-Kawa Z, Majkowska-Skrobek G, Maciejewska B, Delattre A-S, Lavigne R (2012) Learning from bacteriophages: advantages and limitations of phage and phage-encoded protein applications. Curr Protein Pept Sci. 13(8):699-722

84. Summers WC (2001) Bacteriophage therapy. Ann Rev Microbiol. 55(1):437-451

85. Rusckowski M, Gupta S, Liu G, Dou S, Hnatowich DJ (2004) Investigations of a $(99 \mathrm{~m}) \mathrm{Tc}$-labeled bacteriophage as a potential infection-specific imaging agent. J Nucl Med. 45(7):1201-1208

86. Rusckowski M, Gupta S, Liu G, Dou S, Hnatowich DJ (2008) Investigation of four $(99 \mathrm{~m}) \mathrm{Tc}$-labeled bacteriophages for infection-specific imaging. Nucl Med Biol. 35(4):433-440

87. Cardoso ME, Fernandez L, Tejeria E, Esperon P, Teran M (2016) Evaluation of a labelled bacteriophage with $99 \mathrm{mTc}$ as a potential agent for infection diagnosis. Current radiopharmaceuticals. 9(2):137-142

88. Bettegowda C, Foss CA, Cheong I, Wang Y, Diaz L, Agrawal $\mathrm{N}$ et al (2005) Imaging bacterial infections with radiolabeled 1 -(2'-deoxy-2'-fluoro- $\beta$-D-arabinofuranosyl)-5-iodouracil. Proc Natl Acad Sci U S A. 102(4):1145-1150

89. Diaz LA Jr, Foss CA, Thornton K, Nimmagadda S, Endres CJ, Uzuner $O$ et al (2007) Imaging of musculoskeletal bacterial infections by [124I]FIAU-PET/CT. PLoS ONE 2(10):e1007

90. Jacobs A, Voges J, Reszka R, Lercher M, Gossmann A, Kracht L et al (2001) Positron-emission tomography of vector-mediated gene expression in gene therapy for gliomas. Lancet 358(9283):727-729

91. Park JJ, Lee TS, Son JJ, Chun KS, Song IH, Park YS et al (2012) Comparison of cell-labeling methods with (1)(2)(4)I-FIAU and (6)(4)Cu-PTSM for cell tracking using chronic myelogenous leukemia cells expressing HSV1-tk and firefly luciferase. Cancer Biother Radiopharm. 27(10):719-728

92. Zhang XM, Zhang HH, McLeroth P, Berkowitz RD, Mont MA, Stabin MG et al (2016) [124I]FIAU: Human dosimetry and infection imaging in patients with suspected prosthetic joint infection. Nucl Med Biol. 43(5):273-279

93. Wegkamp A, van Oorschot W, de Vos WM, Smid EJ (2007) Characterization of the role of para-aminobenzoic acid biosynthesis in folate production by lactococcus lactis. Appl Environ Microbiol. 73(8):2673-2681

94. Zhang Z, Ordonez AA, Wang H, Li Y, Gogarty KR, Weinstein EA et al (2018) Positron emission tomography imaging with 2-[18F]F-p-aminobenzoic acid detects Staphylococcus aureus infections and monitors drug response. ACS Infect Dis. 4(11):1635-1644

95. Neumann KD, Villanueva-Meyer JE, Mutch CA, Flavell RR, Blecha JE, Kwak T et al (2017) Imaging active infection in vivo using d-amino acid derived pet radiotracers. Sci Rep. 7(1):7903

96. Cho I, Blaser MJ (2012) The human microbiome: at the interface of health and disease. Nature Rev Gen. 13:260-270

97. Sritharan M (2006) Iron and bacterial virulence. Ind J Med Microbiol. 24(3):163-164

98. Petrik M, Franssen GM, Haas H, Laverman P, Hörtnagl C, Schrettl M et al (2012) Preclinical evaluation of two 68Gasiderophores as potential radiopharmaceuticals for Aspergillus fumigatus infection imaging. Eur J Nucl Med Mol Imag. 39(7):1175-1183

99. Petrik M, Haas H, Schrettl M, Helbok A, Blatzer M, Decristoforo $\mathrm{C}$ (2012) In vitro and in vivo evaluation of selected 68Ga-siderophores for infection imaging. Nucl Med Biol. 39(3):361-369 
100. Petrik M, Zhai C, Haas H, Decristoforo C (2017) Siderophores for molecular imaging applications. Clin Transl Imag. 5(1):15-27

101. Petrik M, Haas H, Laverman P, Schrettl M, Franssen GM, Blatzer $\mathrm{M}$ et al (2014) 68Ga-triacetylfusarinine $\mathrm{C}$ and $68 \mathrm{Ga}$-ferrioxamine $\mathrm{E}$ for Aspergillus infection imaging: uptake specificity in various microorganisms. Mol Imaging Biol. 16(1):102-108

102. Heuker M, Sijbesma JWA, Suárez RA, de Jong JR, Boersma HH, Luurtsema G et al (2017) In vitro imaging of bacteria using 18F-fluorodeoxyglucose micro positron emission tomography. Sci Rep. 7(1):4973

103. Signore A, Glaudemans AWJM (2011) The molecular imaging approach to image infections and inflammation by nuclear medicine techniques. Ann Nucl Med. 25(10):681-700

104. Li Z-B, Wu Z, Cao Q, Dick DW, Tseng JR, Gambhir SS et al (2008) The synthesis of 18F-FDS and its potential application in molecular imaging. Mol Imag Biol. 10(2):92-98

105. Scott ME, Viola RE (1998) The use of fluoro- and deoxysubstrate analogs to examine binding specificity and catalysis in the enzymes of the sorbitol pathway. Carbohydr Res. 313(3):247-253

106. Weinstein EA, Ordonez AA, DeMarco VP, Murawski AM, Pokkali S, MacDonald EM, et al. Imaging Enterobacteriaceae infection in vivo with $18 \mathrm{~F}$-fluorodeoxysorbitol positron emission tomography. Sci Transl Med. 2014;6(259):259ra146.

107. Li J, Zheng H, Fodah R, Warawa JM, Ng CK (2018) Validation of 2-(18)F-Fluorodeoxysorbitol as a potential radiopharmaceutical for imaging bacterial infection in the lung. J Nucl Med. 59(1):134-139

108. Yao S, Xing H, Zhu W, Wu Z, Zhang Y, Ma Y et al (2016) Infection imaging with ${ }^{18}$ F-FDS and first-in-human evaluation. Nucl Med Biol. 43(3):206-214

109. Cheng X, Zhu W, Cui R (2016) Increased 18F-2-Fluorodeoxysorbitol (18F-FDS) Activity in a Pituitary Spindle Cell Carcinoma. Clin Nucl Med. 41(12):953-955

110. Ning X, Lee S, Wang Z, Kim D, Stubblefield B, Gilbert E et al (2011) Maltodextrin-based imaging probes detect bacteria in vivo with high sensitivity and specificity. Nature Mat. 10(8):602-607

111. Shuman HA, Treptow NA (1985) The Maltose-Maltodextrintransport system of Escherichia coli K-12. In: Martonosi AN (ed) The Enzymes of Biological Membranes: Volume 3: Membrane Transport. Springer, US, Boston, MA, pp 561-575

112. Shukla J, Arora G, Kotwal PP, Kumar R, Malhotra A, Bandopadhyaya GP (2010) Radiolabeled oligosaccharides nanoprobes for infection imaging. Hell J Nucl Med. 13(3):218-223

113. Ning $X$, Seo W, Lee S, Takemiya K, Rafi M, Feng $X$ et al (2014) Imaging of bacteria PET imaging of bacterial infections with Fluorine-18-labeled maltohexaose. Angew Chem Int Ed. 53(51):14096-14101

114. Gowrishankar G, Namavari M, Jouannot EB, Hoehne A, Reeves $\mathrm{R}$, Hardy J et al (2014) Investigation of 6-[18F]-Fluoromaltose as a novel pet tracer for imaging bacterial infection. PLoS ONE 9(9):e10795

115. Gowrishankar G, Hardy J, Wardak M, Namavari M, Reeves RE, Neofytou E et al (2017) Specific imaging of bacterial infection using 6" -(18)f-fluoromaltotriose: A second-generation pet tracer targeting the maltodextrin transporter in bacteria. J Nucl Med. 58(10):1679-1684

116. Axer A, Hermann S, Kehr G, Clases D, Karst U, Fischer-Riepe L et al (2018) Harnessing the maltodextrin transport mechanism for targeted bacterial imaging: Structural requirements for improved in vivo stability in tracer design. ChemMedChem 13(3):241-250
117. Ferreira IM, de Souza Lacerda CM, de Faria LS, Corrêa CR, de Andrade ASR (2014) Selection of peptidoglycan-specific aptamers for bacterial cells identification. Appl Biochem Biotechnol. 174(7):2548-2556

118. Ellington AD, Szostak JW (1990) In vitro selection of RNA molecules that bind specific ligands. Nature 346:818

119. dos Santos SR, Rodrigues Corrêa C, Branco de Barros AL, Serakides R, Fernandes SO, Cardoso VN, et al. (2015) Identification of Staphylococcus aureus infection by aptamers directly radiolabeled with technetium-99m. Nucl Med Biol 42(3):292-8.

120. Ferreira IM, de Sousa Lacerda CM, Dos Santos SR, de Barros ALB, Fernandes SO, Cardoso VN, et al. (2017) Detection of bacterial infection by a technetium- $99 \mathrm{~m}$-labeled peptidoglycan aptamer. Biomed Pharmacother 93(9):931-8.

121. Nielsen KM, Kyneb MH, Alstrup AKO, Jensen JJ, Bender D, Schønheyder HC et al (2016) 68Ga-labeled phage-display selected peptides as tracers for positron emission tomography imaging of Staphylococcus aureus biofilm-associated infections: Selection, radiolabelling and preliminary biological evaluation. Nucl Med Biol. 43(10):593-605

122. Nielsen KM, Jorgensen NP, Kyneb MH, Borghammer P, Meyer RL, Thomsen TR et al (2018) Preclinical evaluation of potential infection-imaging probe [(68) Ga]Ga-DOTA-K-A9 in sterile and infectious inflammation. J Labelled Comp Radiopharm. 61(10):780-795

123. Liu X, Cheng D, Gray BD, Wang Y, Akalin A, Rusckowski M et al (2012) Radiolabeled Zn-DPA as a potential infection imaging agent. Nucl Med Biol. 39(5):709-714

124. Rice DR, Plaunt AJ, Turkyilmaz S, Smith M, Wang Y, Rusckowski M et al (2015) Evaluation of [111in]-labeled zinc-dipicolylamine tracers for spect imaging of bacterial infection. Mol Imaging Biol. 17(2):204-213

125. Sun T, Tang G, Tian H, Hu K, Yao S, Su Y et al (2015) Positron emission tomography imaging of cardiomyocyte apoptosis with a novel molecule probe [(18)F]FP-DPAZn2. Oncotarget. 6(31):30579-30591

126. Smith BA, Akers WJ, Leevy WM, Lampkins AJ, Xiao S, Wolter $\mathrm{W}$ et al (2010) Optical imaging of mammary and prostate tumors in living animals using a synthetic near infrared Zinc(II)-Dipicolylamine probe for anionic cell surfaces. J Am Chem Soc. 132(1):67-69

127. Rice DR, Vacchina P, Norris-Mullins B, Morales MA, Smith BD (2016) Zinc(II)-dipicolylamine coordination complexes as targeting and chemotherapeutic agents for Leishmania major. Antimicrob Agents Chemother. 60(5):2932-2940

128. Rice DR, Clear KJ, Smith BD (2016) Imaging and therapeutic applications of zinc(ii)-dipicolylamine molecular probes for anionic biomembranes. Chem Commun (Camb). 52(57):8787-8801

129. Lawal I, Zeevaart J, Ebenhan T, Ankrah A, Vorster M, Kruger HG et al (2017) Metabolic imaging of infection. J Nucl Med. 58(11):1727-1732

130. Mollura DJ, Mazal J, Everton KL (2013) White paper report of the 2012 RAD-AID Conference on International Radiology for Developing Countries: planning the implementation of global radiology. J Am Coll Radiol 10(8):618-24.

131. Sajedi S, Sabet H, Choi Hak S (2018) Intraoperative biophotonic imaging systems for image-guided interventions. Nanophotonics. 8(1):99-116

132. Povoski SP, Neff RL, Mojzisik CM, O’Malley DM, Hinkle GH, Hall NC, et al. (2009) A comprehensive overview of radioguided surgery using gamma detection probe technology. World J Nucl Med 7:11 
133. Azhdarinia A, Ghosh P, Ghosh S, Wilganowski N, SevickMuraca EM (2012) Dual-labeling strategies for nuclear and fluorescence molecular imaging: a review and analysis. Mol Imagin Biol. 14(3):261-276

134. Ahn SH, Boros E (2018) Nuclear and optical bimodal imaging probes using sequential assembly: a perspective. Cancer Biother Radiopharm 33(8):308-315
135. Kasper DL (2015) Harrison's principles of internal medicine. 19th ed. Dennis L. Kasper ASF, Stephen L. Hauser, Dan L. Longo, J. Larry Jameson, Joseph Loscalzo (eds.) : McGraw Hill Education Medical, New York

Publisher's Note Springer Nature remains neutral with regard to jurisdictional claims in published maps and institutional affiliations. 